\author{
Doc. dr. sc. Nataša Lucićn \\ Pravni fakultet Sveučilišta u Osijeku
}

\title{
ZASTUPANJE U VEZI S BITNIM OSOBNIM PRAVIMA DJETETA
}

\author{
UDK: $342.7-053.2: 347.6$ \\ DOI:10.31141/zrpfs.2021.58.141.815 \\ Izvorni znanstveni rad \\ Primljeno: 1. veljače 2021.
}

Tema ovoga rada je zastupanje u vezi s bitnim osobnim pravima djeteta u koja se, prema našem obiteljskom zakonodavstvu, u bitnome ubrajaju zastupanja u vezi s promjenom djetetova osobnog imena, promjenom prebivališta odnosno boravišta djeteta i izborom ili promjenom djetetove vjerske pripadnosti. Zastupanje djeteta je primarno pravo i dužnost djetetovih roditelja, čini sadržaj roditeljske skrbi u ostvarivanju koje su roditelji potpuno ravnopravni. U tom smislu, izazov je u situacijama kada ne postoji sporazum roditelja oko bitnih osobnih prava djeteta iznjedriti rješenja kojima će se kod zastupanja u vezi s ovim pravima zaštiti najbolji interesi djeteta, te istovremeno neće ugroziti ravnopravan položaj roditelja kao njegovih zakonskih zastupnika, o čemu se detaljno raspravlja u ovome radu. U radu se isto tako raspravlja i o zastupanju u vezi s bitnim osobnim pravima djeteta kada dijete nema odgovarajuću roditeljsku skrb odnosno ulozi skrbnika u takvim okolnostima. Cilj rada je dati ocjenu postojećeg pravnog stanja u području zastupanja u vezi s bitnim osobnim pravima djeteta, temeljnoj na analizi relevantnih propisa na nacionalnoj, europskoj i međunarodnoj razini, te dati de lege ferenda prijedloge zakonskih promjena koje će pridonijeti većem stupnju ujednačenosti nacionalnog zakonodavstva u ovom području.

Ključne riječi: dijete, zastupanje, bitna osobna prava, roditeljska skrb

\section{UVOD ${ }^{2}$}

Dijete kao osobu bez poslovne sposobnosti zastupaju njegovi zakonski zastupnici što su primarno djetetovi roditelji, a u nedostatku odgovarajuće roditeljske skrbi djetetov skrbnik, te druge osobe kojima u zakonom određenim slučajevima može biti povjereno zastupanje djeteta u pojedinim stvarima. ${ }^{3}$ Konvencija o pravima djeteta $^{4}$ (dalje u tekstu: KPD) propisuje da će radi osiguranja odgovarajućeg usmjeravanja

1 Doc. dr. sc. Nataša Lucić, Sveučilište Josipa Jurja Strossmayera u Osijeku, Pravni fakultet Osijek, Stjepana Radića 13, 31000 Osijek, e-mail: nlucic@pravos.hr

2 Ovaj je rad financirao Pravni fakultet Osijek Sveučilišta Josipa Jurja Strossmayera u Osijeku internim projektom br. IP-PRAVOS-II "Pravna zaštita obitelji i ranjivih skupina društva".

3 Primjerice, kada je zastupanje djeteta u slučajevima predviđenim zakonom radi zaštite pojedinih osobnih i imovinskih prava i interesa djeteta povjereno posebnom skrbniku.

4 Konvencija o pravima djeteta (Narodne novine - Međunarodni ugovori br. 12/93, 20/97, 4/98, 13/98, 5/02, 7/02, 2/03, 2/17, 4/17) 
Doc. dr. sc. Nataša Lucić: Zastupanje u vezi s bitnim osobnim pravima djeteta

Zbornik radova Pravnog fakulteta u Splitu, god. 58, 3/2021, str. 815-840

i vođenja djeteta u ostvarivanju prava priznatih KPD-om države stranke poštivati odgovornosti, prava $i$ dužnosti roditelja, skrbnika ili drugih osoba zakonski odgovornih za dijete (čl. 5.). Pravni odnosi djeteta i njegova zakonskog zastupnika, postizanje balansa između djelovanja umjesto djeteta i djetetovog prava da $\mathrm{u}$ skladu sa svojom dobi i zrelošću samostalno nastupa u zaštiti i promicanju svojih prava, razvoj mehanizama zastupanja prilagođenih djeci, te brojna druga pitanja vezana za zastupanje djeteta, neiscrpna su tema i najrecentnije obiteljskopravne i građanskopravne teorije ${ }^{5}$ i prakse. $^{6}$

Premda nas termin "zastupanje" djeteta najčešće asocira na zastupanja u sudskim i upravnim postupcima, zastupanje djeteta podrazumijeva daleko širu lepezu postupanja i donošenja odluka u ime i za račun maloljetne osobe. Tema ovoga rada je zastupanje djeteta u vezi s bitnim osobnim pravima u koja se sukladno čl. 100. st. 1. Obiteljskoga zakona ${ }^{7}$ (dalje u tekstu: ObZ) ubrajaju:

1. promjena djetetova osobnog imena,

2. promjena prebivališta, odnosno boravišta djeteta $i$

3. izbor ili promjena vjerske pripadnosti. ${ }^{8}$

Pravna pitanja na koje se odnosi zastupanje iz čl. 100. st. 1. ObZ-a predmet su regulacije drugih propisa, a ne obiteljskog zakonodavstva pa je promatrajući iz pozicije djeteta kao osobe koju je u tim vrlo osjetljivim pitanjima potrebno zastupati, ali i onih na kojima leži teret zastupanja, usklađenost obiteljskog i drugih relevantnih propisa u ovom području iznimno važna. U tom smislu, u radu će se detaljno analizirati relevantne odredbe ObZ-a, ali i drugih propisa važnih za sveobuhvatno razumijevanje pravne regulacije zastupanja djeteta u vezi s bitnim osobnim pravima, te dati ocjena njihove (ne)usklađenosti.

Najprije će se generalno raspraviti o zastupanju u vezi s (bitnim) osobnim pravima djeteta kao sadržaju roditeljske skrbi. Potom će se posebno analizirati pravna regulacija zastupanja djeteta od strane roditelja u vezi s promjenom osobnog

5 Vidi, primjerice, komparativnu analizu zastupanja djeteta u obiteljskim postupcima u Mol, 2019; argumentaciju koja govori o važnosti poštivanja djetetove autonomije u Daly, 2018; relevantna stajališta pravnih teoretičara u Liefaard i Sloth-Nielsen, 2017. itd.

6 I ESLJP je u svojoj praksi upućivao na neke odrednice za postizanje veće uspješnosti u zastupanju djece. Tako je, primjerice, u slučaju Paradiso i Campanelli protiv Italije, Zahtjev br. 25358/12, Odluka od 24. siječnja 2017., ESLJP istaknuo da je potrebno izbjegavati restriktivni i čisto tehnički pristup u pogledu zastupanja djece pred institucijama EKLJP, te da je kod zastupanja djeteta posebno važno razmotriti vezu između djeteta i njegovog zastupnika, te mogućnost postojanja sukoba interesa. Upravo je sumnja u postojanje sukoba interesa između djeteta i majke koja je trebala zastupati dijete ponukala ESLJP da u jednom od novijih predmeta koji se pred tim sudom vodio protiv Hrvatske, predmetu A. i B. protiv Hrvatske (Zahtjev br. 7144/15 , Odluka od 20. lipnja 2019.) zahtijeva imenovanje posebnog zastupnika djeteta od Hrvatske odvjetničke komore.

7 Obiteljski zakon (Narodne novine br. 103/15, 98/19)

8 U čl. 100. st. 6. ObZ-a propisano je da je za priznanje, odnosno za pristanak na priznanje očinstva koje je dalo dijete u odnosu na očinstvo vlastitoga djeteta potrebna pisana suglasnost oba roditelja koja imaju pravo zajednički zastupati dijete, isto kao što je i slučaj s zastupanjima u vezi s bitnim osobnim pravima djeteta iz čl. 100. st. 1. Međutim, utvrđivanje očinstva priznanjem, pa tako i davanje suglasnosti roditelja iz čl. 100. st. 6., obiteljskopravna je tema kojoj je uputno posvetiti znanstveno istraživačku pažnju u posebnom radu, te se o toj temu u ovome radu ne raspravlja. 
imena, promjenom prebivališta odnosno boravišta, te izborom ili promjenom vjerske pripadnosti. Raspraviti će se i o zastupanju u vezi s bitnim osobnim pravima djeteta kada dijete nema odgovarajuću roditeljsku skrb, te u tom smislu ulozi skrbnika u takvim okolnostima. Zaključno će se osim ocjene pravnog stanja temeljene na analizi relevantnih nacionalnih, ali i međunarodnih i europskih normi dati i određeni de lege ferenda prijedlozi, te uputa na daljnja istraživanja u ovom području.

\section{ZASTUPANJE U VEZI S (BITNIM) OSOBNIM PRAVIMA DJETETA KAO SADRŽAJ RODITELJSKE SKRBI}

Briga o djetetu, te usmjeravanje i vođenje djeteta u ostvarivanju njegovih prava, prvenstveno je pravo i dužnost roditelja. I sam Ustav Republike Hrvatske ${ }^{9}$ (dalje u tekstu: Ustav RH) prepoznaje roditelje kao osobe koje su prije svih pozvane pružiti djetetu odgovarajuću skrb, osigurati mu potpun i skladan razvoj njegove osobnosti i jamči roditeljima slobodu samostalnog odlučivanja o odgoju djeteta (čl. 64. st. 1. i 2.). Naše se obiteljsko zakonodavstvo temelji na načelu ravnopravnosti žene i muškarca u obiteljskopravnim odnosima, a osobito u odnosu na roditeljsku skrb. ${ }^{10}$ U tom smislu, roditelji imaju pravo i dužnost ravnopravno, zajednički i sporazumno ostvarivati roditeljsku skrb, a kada roditelji trajno ne žive zajedno, dužni su ostvarivanje roditeljske skrbi sporazumno urediti planom o zajedničkoj roditeljskoj skrbi (čl. 104. st. 1. i 2.). ${ }^{11}$ Isto tako, brak nije pretpostavka uživanja zajedničke roditeljske skrbi, pa roditelji koji ostvaruju životnu zajednicu izvan braka uživaju zajedničku roditeljsku skrb ex lege, kao i roditelji u braku. Zajedničko ostvarivanje roditeljske skrbi se može urediti i odlukom suda temeljenoj na sporazumu roditelja o svim bitnim pitanjima iz plana o zajedničkoj roditeljskoj skrbi (čl. 104. st. 4.).

Roditeljsku skrb ObZ definira kao skup odgovornosti, dužnosti i prava roditelja, u svrhu zaštite i promicanja djetetovih osobnih $i$ imovinskih prava te dobrobiti (čl. 91. st. 1.), te propisuje da su roditelji dužni o pojedinačnim sadržajima roditeljske skrbi razgovarati i sporazumijevati se s djetetom u skladu s njegovom dobi i zrelošću (čl. 91. st. 3.). U sadržaj roditeljske skrbi ulazi pravo i dužnost zaštite osobnih prava djeteta $^{12}$, te pravo i dužnost upravljanja djetetovom imovinom, a u zakonu se izričito navodi da u sadržaj roditeljske skrbi ulazi i pravo i dužnost zastupanja djetetovih osobnih i imovinskih prava i interesa (čl. 92).

9 Ustav Republike Hrvatske (Narodne novine br. 56/90, 135/97, 113/00, 28/01, 76/10, 5/14)

10 Ovo je prvo načelo obiteljskog zakonodavstva, propisano u čl. 3. ObZ-a.

11 Plan o zajedničkoj roditeljskoj skrbi ObZ-om je definiran kao pisani sporazum roditelja o načinu ostvarivanja zajedničke roditeljske skrbi u okolnostima u kojima roditelji djeteta trajno ne žive u obiteljskoj zajednici (čl. 106. st. 1.). Njime se roditelji trebaju sporazumjeti o mjestu i adresi djetetova stanovanja, vremenu koje će dijete provoditi sa svakim od roditelja, načinu razmjene informacija u vezi s davanjem suglasnosti pri donošenju odluka bitnih za dijete, te razmjene važnih informacija u vezi s djetetom, visini uzdržavanja djeteta i načinu rješavanja buduća sporna pitanja u ostvarivanju zajedničke roditeljske skrbi (čl. 106. st. 2.).

12 Prava na zdravlje, razvoj, njegu i zaštitu, odgoj i obrazovanje, ostvarivanje osobnih odnosa i određivanje mjesta stanovanja. 
ObZ obvezuje roditelje koji ostvaruju roditeljsku skrb na sporazumno zastupanje svojega djeteta u odnosu prema trećima (čl. 99. st. 1.), te propisuje da se načelno smatra da je jedan roditelj dao svoj pristanak drugom roditelju da može zastupati dijete bez njegove izričite suglasnosti (čl. 99. st. 2.). ${ }^{13}$ Međutim, kada su u pitanju zastupanja u vezi s bitnim osobnim ili imovinskim pravima ${ }^{14}$ djeteta, suglasnost drugog roditelja se nikada ne presumira. Da bi jedan roditelj valjano zastupao dijete $\mathrm{u}$ vezi s bitnim osobnim pravima djeteta, a koja se kako je prethodno navedeno odnose na promjenu djetetova osobnog imena, promjenu prebivališta, odnosno boravišta djeteta i izbor ili promjenu vjerske pripadnosti, nije dovoljno da ima pravo na ostvarivanje roditeljske skrbi te ujedno i na zastupanje djeteta, nego je potrebno i da pribavi pisanu suglasnost drugog roditelja koji ima pravo zastupati dijete (čl. 100. st. 2.) ${ }^{15}$ Jasno da je osjetljivost odlučivanja u vezi s bitnim osobnim pravima djeteta ponukala zakonodavca da valjanost zastupanja djeteta u ovom području uvjetuje postojanjem izričite suglasnosti oba roditelja, te da se u tom smislu kada dijete zastupa jedan roditelj zahtjeva, tragom pravne sigurnosti, pisana suglasnost drugog roditelja. Međutim, zanimljivo je da istovremeno zakon ne govori ništa o načinu dokazivanja autentičnosti takve pisane suglasnosti. Nije, dakle, propisana obveza izjave suglasnosti pred i/ili uz ovjeru potpisa nadležnog tijela.

Ako zajednički ostvaruju roditeljsku skrb, oba roditelja imaju pravo zastupanja djeteta, a ako jedan roditelj samostalno ostvaruje roditeljsku skrb onda samo taj roditelj ima pravo zastupati dijete. Međutim, i ovdje postoji iznimka kada je u pitanju zastupanje u vezi s bitnim osobnim pravima djeteta. Naime, kada sud donosi odluku o samostalnom ostvarivanju roditeljske skrbi, odredit će hoće li roditelj koji samostalno ostvaruje roditeljsku skrb sam zastupati dijete u bitnim osobnim pravima ili uz suglasnost drugog roditelja (čl. 105. st. 5.). Dakle, i kada je ostvarivanje roditeljske skrbi povjereno samo jednom roditelju, drugi roditelj ipak može temeljem odluke suda imati pravo suodlučivanja u vezi s bitnim osobnim pravima djeteta.

13 Važno je istaknuti i to da jedan roditelj samostalno zastupa dijete u onim područjima roditeljske skrbi u kojima je drugi roditelj ograničen. U žurnim slučajevima, kad prijeti opasnost za život i zdravlje djeteta, svaki od roditelja ima pravo poduzeti nužne pravne radnje u skladu s dobrobiti djeteta i o tome odmah obavijestiti drugog roditelja (čl. 99. st. 3. i 4.).

14 Prema čl. 101. ObZ-a, zastupanje djeteta u vezi s njegovom vrjednijom imovinom, odnosno imovinskim pravima smatraju se zastupanja u vezi otuđenja i opterećenja nekretnina, pokretnina koje se upisuju u javne upisnike ili pokretnina veće vrijednosti, raspolaganja dionicama i poslovnim udjelima, raspolaganja nasljedstvom, prihvaćanja darova s teretom ili odbijanja ponuđenih darova te raspolaganja drugim vrjednijim imovinskim pravima, ovisno o okolnostima pojedinoga slučaja, te zastupanje prigodom sklapanja ugovora između djeteta i fizičkih ili pravnih osoba kojima je predmet raspolaganje budućim imovinskim pravima djeteta u vezi s njegovim sportskim, umjetničkim ili sličnim aktivnostima. Za valjano zastupanje djeteta u vezi s njegovom vrjednijom imovinom, odnosno imovinskim pravima potrebna je ne samo pisana suglasnost drugog roditelja koji ostvaruje roditeljsku skrb, nego i odobrenje suda u izvanparničnom postupku.

15 Određene su iznimke od pribavljanja suglasnosti drugog roditelja propisane kada je u pitanju zastupanje u vezi s promjenom djetetova prebivališta odnosno boravišta. O tome više u 4. poglavlju ovoga rada. 
Važno je naglasiti i to da kada roditelji zajednički ostvaruju roditeljsku skrb, odluke koje su bitne za dijete ${ }^{16}$, kao i suglasnosti dužni su donijeti, odnosno dati sporazumno (čl. 108. st. 1.). Isto tako, prilikom zajedničkog ostvarivanja roditeljske skrbi roditelji su dužni sporna pitanja pokušati riješiti sporazumno (čl. 104. st. 4.). Kada se roditelji koji imaju pravo zastupati dijete ne mogu sporazumjeti u vezi s bitnim odlukama koje se odnose na osobna prava djeteta, na prijedlog djeteta ili roditelja sud u izvanparničnom postupku donosi odluku o tome koji će od roditelja u toj stvari zastupati dijete, a roditelji su prije pokretanja izvanparničnog postupka dužni sudjelovati u postupku obveznog savjetovanja ${ }^{17}$ (čl. 109. st. 1. i 2.). Ako roditelji ove postupke pokreću učestalo, sud može na zahtjev djeteta ili roditelja povjeriti ostvarivanje roditeljske skrbi djelomice ili u potpunosti samo jednom roditelju (čl. 109. st. 3.).

Poznato je da je usvajanje KPD-a značajno utjecalo na razvoj shvaćanja kako je, iako u nedostatku poslovne sposobnosti treba zakonskoga zastupnika, dijete aktivan sudionik u zaštiti i promicanju svojih prava. ${ }^{18} \mathrm{U}$ čl. 12. KPD obvezuje države potpisnice da osiguraju djetetu koje je u stanju oblikovati vlastito mišljenje, pravo na slobodno izražavanje vlastitih stavova o svim stvarima koje se na njega odnose, te uvažavanje djetetovih stavova sukladno dobi i zrelosti djeteta. U skladu s ovom konvencijskom odredbom ObZ propisuje da su roditelji i druge osobe koje skrbe o djetetu dužni poštovati mišljenje djeteta u skladu s njegovom dobi i zrelošću (čl. 86. st. 1.). Prema tome, kao zakonski zastupnici djeteta roditelji su dužni uključiti dijete u donošenje svih vrsta odluka koje se na njega odnose, pa tako i odluka u vezi s promjenom njegova imena, mjesta stanovanja i vjerske pripadnosti. O mehanizmima zaštite djetetova prava na izražavanje mišljenja kod zastupanja djeteta u vezi s ovim pravnim pitanjima, detaljnije će se raspraviti u idućim poglavljima.

16 Odluke koje su bitne za dijete osim odluka koje se odnose na zastupanje u vezi s bitnim osobnim pravima djeteta iz čl. 100. ObZ-a i i zastupanje u vezi s vrjednijom imovinom i imovinskim pravima djeteta iz čl. 101. ObZ-a, mogu biti i druge odluke koje mogu znatno utjecati na život djeteta kao što je ostvarivanje osobnih odnosa s djetetu bliskim osobama, izvanredni medicinski postupci ili liječenje te izbor škole za koje odluke se smatra da je drugi roditelj dao svoju suglasnost (čl. 108. st. 3.).

17 Obvezno savjetovanje je postupak koji provodi centar za socijalnu skrb, a zakonom se definira kao oblik pomoći članovima obitelji da donesu sporazumne odluke o obiteljskim odnosima vodeći posebnu brigu o zaštiti obiteljskih odnosa u kojima sudjeluje dijete te o pravnim posljedicama nepostizanja sporazuma i pokretanju sudskih postupaka u kojima se odlučuje o osobnim pravima djeteta (čl. 321. st. 1.).

18 Uz uvažavanje uloge roditelja u ostvarivanju prava djeteta zajamčenih KPD-om, sljedeći važan čimbenik KPD-a je prepoznavanje potencijala samoga djeteta i njegove sve veće autonomije kao ključnih faktora za ono što nazivamo "sudjelovanje djeteta" (Doek, 2019, str. 14-15). Djetetovo pravo na izražavanje mišljenja i drugi oblici aktivnog sudjelovanja djeteta u kreiranju odluka i politika koje se na njega izravno ili neizravno odnose aktualna su tema u vrlo različitim pravnim područjima, od iskazivanja mišljenja u sudskim postupcima (vidi, primjerice, Daly, 2018; Rap, 2017), do sudjelovanja djeteta u području zdravstvene zaštite (Guerreiro i Flotten, 2017) i kreiranja politika zaštite okoliša i održivog razvoja (vidi, primjerice, Arts, 2019; Lucić i Marošević, 2020). 


\section{PROMJENA DJETETOVA OSOBNOG IMENA}

Osobno ime je sastavni element osobnosti svakog čovjeka: označava identitet njegova nositelja i odražava ga u obiteljskom te u društvenom kontekstu (Winkler, 2013, str. 125; Winkler, 2014, str. 885). Pravo na osobno ime kao pravo djeteta koje mu pripada od trenutka njegova rođenja zaštićeno je kroz nekoliko međunarodnih dokumenata nastalih pod okriljem Ujedinjenih naroda. Tako, primjerice, Međunarodni pakt o građanskim i političkim pravima ${ }^{19}$ u čl. 24. st. 2. propisuje da svako dijete mora biti registrirano u matične knjige i dobiti ime neposredno nakon rođenja (čl. 24. st. 2.). Isto tako, KPD u čl 7. st. 1. propisuje da odmah nakon rođenja dijete mora biti upisano u matične knjige te mu se mora jamčiti pravo na ime. U st. 2. istoga članka obvezuje države potpisnice da osiguraju djetetu primjenu toga prava $u$ skladu sa svojim nacionalnim zakonodavstvom i obvezama koje proizlaze iz odgovarajućih međunarodnih instrumenata u ovom području..$^{20}$

Europski instrumenti za zaštitu ljudskih prava ne jamče izričito pravo djetetu na osobno ime od trenutka njegova rođenja. Europska Konvencija za zaštitu ljudskih prava i temeljnih sloboda ${ }^{21}$ (dalje u tekstu: EKLJP) kao najvažniji europski dokument za zaštitu temeljnih prava svakog čovjeka pa tako i djeteta ${ }^{22}$, ne sadrži odredbu kojom eksplicitno štiti pravo na ime, ali je ono ipak sadržano u konvencijom zaštićenom pravu na privatni i obiteljski život (čl. 8.) utoliko što odgovara čovjekovom pravu na vlastiti identitet (Kilkelly, 2017, str. 111). ${ }^{23}$ Razvoj svijesti o ravnopravnoj ulozi roditelja kod određivanja osobnog imena djeteta tekao je paralelno s prihvaćanjem principa ravnopravnosti spolova kada je u pitanju promjena osobnog imena, točnije prezimena, prilikom sklapanja braka. Europska komisija za ljudska prava je u slučaju Hagmann-Hüsler protiv Švicarske ${ }^{24}$ uzimajući u obzir potrebu identificiranja članova obitelji njihovim obiteljskim imenom od strane trećih osoba, odbila ocijeniti diskriminatornim švicarsko zakonodavstvo koje je predviđalo da žena prilikom sklapanja braka može preuzeti muževo prezime, ali ne i obratno, tim više jer su tada slično predviđala i brojna druga europska zakonodavstva. Međutim, do preokreta je došlo u slučaju Burghartz protiv Švicarske $e^{25}$ kada je ESLJP odbio argumentaciju da je zakonodavstvo koje kao mogućnost predviđa samo da žena

19 Međunarodni pakt o građanskim i političkim pravima (Narodne novine - Međunarodni ugovori br. $12 / 93,7 / 95,11 / 95)$

20 I Konvencija o pravima osoba s invaliditetom (Narodne novine - Međunarodni ugovori br. 6/07, $3 / 08,5 / 08$ ) se referira na pravo djeteta na osobno ime, te u čl. 18. st. 2. obvezuje da djeca s teškoćama u razvoju budu evidentirana odmah po rođenju i od rođenja im jamči pravo na ime.

${ }_{21}$ Konvencija za zaštitu ljudskih prava i temeljnih sloboda (Narodne novine - Međunarodni ugovori br. 18/97, 6/99, 8/99, 14/02, 13/03, 9/05, 1/06, 2/10, 13/17)

22 Polazna točka za razumijevanje dječjih prava zaštićenih EKLJP činjenica je da djeci EKLJP jamči ista prava kao i odraslim osobama (Choudhry i Herring, 2010, str. 222).

${ }_{23}$ U svojoj odluci u slučaju Losonci Rose i Rose protiv Švicarske, Zahtjev br. 664/06, Odluka od 9. studenog 2010., ESLJP je naveo kako je osobno ime glavno sredstvo osobne identifikacije u društvu, "jedan od ključnih aspekata koji treba uzeti u obzir u vezi s pravom na poštivanje privatnog i obiteljskog života".

24 Hagmann-Hüsler protiv Švicarske, Zahtjev br. 8042/77, Odluka od 15. prosinca 1997.

25 Burghartz protiv Švicarske, Zahtjev br. 16213/90, Odluka od 22. veljače 1994. 
Doc. dr. sc. Nataša Lucić: Zastupanje u vezi s bitnim osobnim pravima djeteta

Zbornik radova Pravnog fakulteta u Splitu, god. 58, 3/2021, str. 815-840

preuzme muževo prezime odraz nacionalne tradicije, te zaključio kako je uvažavajući principe ravnopravnosti spolova neprihvatljivo shvaćanje da se postojanje obiteljske zajednice ne bi moglo reflektirati zajedničkim obiteljskim prezimenom i na način da muškarac preuzme suprugino prezime. ${ }^{26}$ Nadalje, u slučaju Ünal Tekeli protiv Turske $^{27}$ ESLJP izražava stajalište da zajedničko prezime supružnika uopće niti nije nužan preduvjet prepoznavanja postojanja obiteljske zajednice, te da nema konkretnih ili suštinskih teškoća za same supružnike ili treće osobe ili pak štete za javni interes koji bi mogao biti rezultat nedostatka zajedničkog prezimena kao izraza njenog postojanja. ${ }^{28}$

Postupno prihvaćanje principa spolne ravnopravnosti vezano uz odabir prezimena prilikom sklapanja braka imalo je naravno svoje implikacije i na uvažavanje roditeljske ravnopravnosti vezano uz određivanje osobnog imena djeteta. ESLJP je u predmetu Cuzan i Fazzo protiv Italije ${ }^{29}$ zaključio da diskriminacija postoji kada se zajedničkoj djeci supružnika automatski određuje očevo prezime čak i kada su se supružnici sporazumjeli drugačije. Ipak, u slučaju Bijleveld protiv Nizozemske ${ }^{30}$ ESLJP je iz svojevrsnih pragmatičnih razloga zakonitim ocijenio pravilo da se u nedostatku konsenzusa među supružnicima, djetetu automatski određuje očevo prezime (prema Ravasi, 2017, str. 178). Određivanje osobnog imena djeteta od strane roditelja ESLJP drži privatnom obiteljskom sferom ${ }^{31}$, pa u tom smislu ograničavanje roditelja u donošenju odluka vezanih uz osobno ime djeteta može značiti povredu prava na privatni i obiteljski život (Kilkelly, 2017, str. 113). Međutim, to ipak ne znači da ne trebaju postojati mehanizmi zaštite interesa djeteta u situacijama kada roditelji namjeravaju djetetu odrediti ime koje bi bilo pogrdno ili društveno neprikladno i neprihvatljivo. U slučaju Guillot protiv Francuske ${ }^{32}$ ESLJP je utvrdio da iako je nesporno da ovaj predmet ulazi u sferu zaštite prava na privatni

26 Zanimljivost ovoga slučaja ogleda se i u činjenici što se upravo muškarac koji nije mogao preuzeti ženino djevojačko prezime pred nadležnim nacionalnim tijelima žalio na diskriminatorno postupanje. U većini drugih slučajeva u ovom području su na diskriminatoran položaj u odnosu na muškarce upućivale žene, a ne obratno.

27 Ünal Tekeli protiv Turske, Zahtjev br. 29865/96, Odluka od 6. studenog 2004. Podnositeljica zahtjeva je u svom profesionalnom životu kao odvjetnica bila poznata po svom djevojačkom prezimenu. Kako nakon sklapanja braka nije mogla koristiti oba prezimena na službenim dokumentima, podnijela je zahtjev da joj se dopusti da se služi samo svojim djevojačkim prezimenom "Ünal". Obzirom da joj je takav zahtjev odbijen s obrazloženjem da zakon obvezuje žene da nakon sklapanja braka preuzmu muževo prezime, obratila se ESLJP zbog povrede čl. 8. i čl. 14. EKLJP. Iako je podnositeljica istaknula problem koji joj je promjena prezimena uzrokovala vezano za prepoznavanje u profesionalnom životu, zanimljivo je da se toj činjenici u samoj presudi nije pridodavala velika važnost što je i opravdano jer spolna jednakost treba biti prihvaćena kao princip neovisno o okolnostima koje odstupanje od tog principa uzrokuje u konkretnom slučaju (Draghici, 2017, str. 259).

${ }_{28}$ U to vrijeme Turska je bila jedina članica Vijeća Europe u kojoj je ženi bila nametnuta obveza preuzimanja muževa prezimena čak i kada postoji konsenzus među supružnicima da žena zadrži svoje prezime (vidi odluku u predmetu Ünal Tekeli protiv Turske, toč. 61.).

29 Cuzan i Fazzo protiv Italije, Zahtjev br. 77/07, Odluka od 7. siječnja 2014.

30 Bijleveld protiv Nizozemske, Zahtjev br. 42973/98, Odluka od 27. travnja 2000.

31 U odluci u predmetu Guillot protiv Francuske (Zahtjev br. 22500/93, Odluka od 24. listopada 1993.), ESLJP izražava stajalište da je " odabir djetetova imena od strane roditelja osobna, emocionalna stvar i stoga ulazi u njihovu privatnu sferu" (toč. 23).

32 Guillot protiv Francuske, Zahtjev br. 22500/93, Odluka od 24. listopada 1996. 
i obiteljski život u konkretnom slučaju nije došlo do povrede čl. 8. EKLJP zbog toga što nadležna nacionalna tijela Francuske nisu dopustila roditeljima registraciju imena Fleur de Marie njihovoj kćeri:

"27. Sud može razumjeti da su g. i gđa Guillot uznemireni odbijanjem registracije imena koje su odabrali za svoju kćer. Primjećuje da se stoga ovo ime ne može pojaviti u službenim dokumentima $i$ ispravama. Uz to, smatra vjerojatnim da razlika između djetetovog registriranog imena i imena koje zapravo koristi - obitelj je naziva "Fleur de Marie", a pod tim imenom se i društveno prepoznaje - povlači za sobom određene komplikacije za podnositelje zahtjeva kada djeluju kao njezini zakonski zastupnici. Međutim, Sud primjećuje da nije sporno da dijete redovito neometano koristi dotično ime i da su francuski sudovi - koji su uzimali u obzir djetetov interes - alternativno dopustili podnositeljima zahtjeva registraciju imena "Fleur-Marie"(...). U svjetlu gore navedenog, Sud ne nalazi da je neugodnost na koju se žale podnositelji zahtjeva dovoljna da dovede u pitanje nepoštivanja njihova privatnog i obiteljskog života prema članku 8. stavku. 1 (čl. 8-1). Prema tome, nije došlo do povrede članka 8. (čl. 8)."

I u predmetu Johansson protiv Finske ${ }^{33}$ radilo se o onemogućavanju roditeljima da registriraju osobno ime djetetu koje su oni željeli, no u ovom je predmetu ESLJP zaključio o povredi čl. 8. EKLJP. Naime, nadležna tijela Finske su odbila registrirati ime "Axl Mick" jer način pisanja ovog imena nije usklađen s finskom praksom određivanja imena. ESLJP se složio sa stajalištem da je potrebno slijediti djetetove najbolje interese kao i da je očuvanje nacionalne prakse određivanja imena javni interes, no ipak je zaključio da se ime koje su roditelji željeli registrirati ne može smatrati neprikladnim za dijete. Isto tako, uzimajući u obzir da nije utvrđeno da je ime negativno utjecalo na kulturni i lingvistički identitet države, ESLJP je zaključio da pitanje javnog interesa nije važnije od interesa upisivanja djeteta pod imenom koji su odabrali roditelji.

Promatrajući ovo pitanje u nacionalnim okvirima ${ }^{34}$ generalno se može zaključiti o ravnopravnom položaju roditelja kada je u pitanju zastupanje djeteta vezano uz određivanje i/ili promjenu njegova osobnog imena. Međutim, dublja analiza relevantnog zakonodavstva upućuje na zaključak o postojanju određenih zakonskih antinomija koje bi u slučaju nepažljivog pristupa njihovom rješavanju mogle rezultirati nejednakim postupanjima u pravnoj praksi.

Najprije je ovdje važno ponoviti da je obzirom da ObZ promjenu djetetova imena ubraja u zastupanje u vezi s bitnim osobnim pravima djeteta ono valjano samo ako roditelj koji zastupa dijete ima pisanu suglasnost drugog roditelja koji ima pravo zastupati dijete. ObZ se ne dotiče pitanja određivanja nego samo promjene djetetova osobnog imena. Određivanje i promjena osobnog imena predmet je regulacije

33 Johansson protiv Finske, Zahtjev br. 10163/02, Odluka od 6. rujna 2007.

34 I u domaćoj građanskopravnoj teoriji prevladava gledište koje pravo na ime svrstava u sustav prava osobnosti, ne kao samostalno nego uključeno u kompleks prava na osobni identitet kojim se osim imena štite i drugi znakovi individualizacije pojedinca (Dropulić, 2006, str. 12.; vidi i Radolović, 1998, str. 82; Gavella, 2000, str. 30). 
Zakona o osobnom imenu ${ }^{35}$ (dalje: ZOI) koji sadrži posebne odredbe o određivanju i promjeni osobnog imena djeteta. Vezano za određivanje osobnog imena djeteta, ovaj zakon propisuje da osobno ime djeteta određuju roditelji sporazumno, a ako se roditelji nisu sporazumjeli o osobnom imenu djeteta, osobno ime određuje nadležni centar za socijalnu skrb u roku od trideset dana od dana podnošenja zahtjeva jednog od roditelja (čl. 3. st. 1. i 3.). Ako roditelji nisu djetetu odredili osobno ime u zakonom predviđenom roku, što je trideset dana od dana rođenja djeteta, matičar koji je nadležan za upis toga djeteta u maticu rođenih ima obvezu o tome izvijestiti nadležni centar za socijalnu skrb radi određivanja osobnog imena djeteta (čl. 3. st. 7.).

Što se tiče promjene osobnog imena djeteta, ZOI jednako kao i ObZ, promjenu osobnog imena djeteta u čl. 7. st. 1. povjerava prvenstveno roditeljima, te propisuje da će se djetetu promijeniti osobno ime na zahtjev oba roditelja. ${ }^{36}$ Međutim, ono što je sporno je to što ZOI u čl. 7. st. 2., kada je u pitanju promjena osobnog imena djeteta, pravi razliku između roditelja ovisno o njihovom (izvan)bračnom statusu: Osobno ime maloljetnog djeteta čiji roditelji nisu u braku, promijenit će se na zahtjev roditelja kod kojega dijete živi ili kojemu je povjereno sukladno pravomoćnoj sudskoj odluci, uz suglasnost drugog roditelja. Proizlazi, dakle, dovedu li se u vezu st. 1. i 2. čl. 7. ZOI-a, da se osobno ime djeteta mijenja na zahtjev oba roditelja samo ako su roditelji u braku, a ako nisu u braku na zahtjev roditelja kod kojeg dijete živi odnosno, kojemu je povjereno sukladno pravomoćnoj sudskoj odluci, uz suglasnost drugog roditelja. Ovdje je vidljiva neusklađenost ZOI-a s obiteljskim zakonodavstvom u nekoliko segmenata. Najprije, važno je naglasiti da ObZ ne čini nikakvu razliku u zastupanju djeteta između roditelja koji zajednički ostvaruju roditeljsku skrb ovisno o pravnom temelju za ostvarivanje zajedničke roditeljske skrbi. Dakle, na roditelje koji zajednički ostvaruju roditeljsku skrb jer žive u braku ili u izvanbračnoj zajednici, kao i na roditelje koji zajedničku roditeljsku skrb ostvaruju temeljem plana o zajedničkoj roditeljskoj skrbi, primjenjuju se iste odredbe ObZ-a o zastupanju u vezi s bitnim osobnim pravima djeteta. Prema tome, zastupanje u vezi s promjenom djetetova imena je valjano samo ako roditelj koji zastupa dijete (a to može biti i roditelj koji živi i roditelj koji ne živi s djetetom) ima pisanu suglasnost drugog roditelja koji ima pravo zastupati dijete. ZOI, međutim, propisuje da se ako roditelji ne žive u braku osobno ime djeteta može promijeniti na zahtjev roditelja kod kojeg dijete živi ili kojemu je povjereno sukladno pravomoćnoj sudskoj odluci, uz suglasnost drugog roditelja. Proizlazi da roditelj s kojim dijete ne živi, neovisno što roditelji ostvaruju zajedničku roditeljsku skrb, ne može podnijeti zahtjev za promjenu osobnog imena djeteta, te da roditelji koji zajednički ostvaruju roditeljsku skrb na temelju izvanbračnog suživota ili temeljem pisanog sporazuma o zajedničkoj roditeljskoj skrbi ne mogu zajednički zahtijevati promjenu osobnog imena djeteta, što životno i pravno nije suvislo i prihvatljivo. Neprikladan

\footnotetext{
35 Zakon o osobnom imenu (Narodne novine br. 118/12, 70/17 i 98/19)

36 Ako je dijete bez odgovarajuće roditeljske skrbi te je zbog toga pod skrbništvom, zahtjev za promjenu osobnog imena podnosi skrbnik uz suglasnost nadležnog centra za socijalnu skrb. O tome više u 6. poglavlju ovoga rada.
} 
je i zakonski izričaj "roditelj kojemu je dijete povjereno sukladno pravomoćnoj sudskoj odluci". Naime, u zakonom predviđenim okolnostima sud može donijeti odluku o samostalnom ostvarivanju roditeljske skrbi odnosno može donijeti odluku kojom povjerava djelomice ili u potpunosti ostvarivanje roditeljske skrbi jednom od roditelja, a ne kojom povjerava dijete jednom od roditelja, kako to u citiranom čl. 7. st. 2. propisuje ZOI. Nije potrebno posebno naglašavati koliko je važno paziti na usklađenost u pravnoj terminologiji među propisima i negativne posljedice koje takve neusklađenosti mogu prouzročiti kod primjene propisa u pravnoj praksi pa je ZOI i u terminološkom smislu svakako potrebno uskladiti s ObZ-om.

Za slučaj nepostojanja suglasnosti odnosno rješavanja spora roditelja za promjenu osobnog imena djeteta, ZOI upućuje na obiteljsko zakonodavstvo. ${ }^{37}$ Vidljivo je da je zakonodavac ZOI-om i ObZ-om propisao nadležnosti različitih tijela ovisno o tome postoji li neslaganje roditelja oko određivanja osobnog imena djeteta ili oko promjene osobnog imena djeteta, kao i različitu proceduru za rješavanje ovih pitanja. Tako će ako su roditelji zbog neslaganja oko osobnog imena djeteta propustili djetetu odrediti osobno ime u zakonom predviđenom roku, primjenom odgovarajućih odredbi ZOI-a, osobno ime djetetu odrediti mjesno nadležni centar za socijalnu skrb. Ako, pak, postoji neslaganje roditelja oko promjene osobnog imena djeteta sud će u izvanparničnom postupku, primjenom odgovarajućih odredbi ObZ-a, odlučiti o tome koji će od roditelja u toj pravnoj stvari zastupati dijete, uz obvezu da roditelji prije pokretanja sudskog postupka sudjeluju u postupku obveznog savjetovanja. Ne može se ne primijetiti da je zakonodavac predvidio dosta složeniju proceduru kod rješavanja pitanja neslaganja roditelja oko promjene, u odnosu na neslaganje roditelja oko određivanja osobnog imena djeteta. Postavlja se pitanje (ne)opravdanosti takvog pravnog stanja. Jasno je da u situacijama kada roditelji nisu u zakonskom roku odredili osobno ime djetetu radi zaštite djetetovih interesa treba pojednostaviti proceduru kojom će se u što krećem roku djetetu odrediti osobno ime s kojim će se dijete služiti u pravnom prometu. Ipak, ostaje nejasno zbog čega zakonodavac upućuje na nadležnost centra za socijalnu skrb kada se roditelji ne mogu sporazumjeti oko određivanja, ali ne i kada se ne mogu sporazumjeti oko promjene djetetova osobnog imena. Dvojbena je i (ne)opravdanosti reguliranja ovih vrlo srodnih pravnih pitanja dvama različitim propisima, što svakako prouzrokuje složenost kod njihova rješavanja u praksi.

Kada je u pitanju određivanje osobnog imena posvojenog djeteta, ZOI, također, upućuje na obiteljsko zakonodavstvo (čl. 3. st. 6.). Posvojenjem se stvara neraskidiv odnos srodstva između posvojitelja i posvojenika i sva prava i dužnosti koja iz tog odnosa proizlaze. Prema tome, kao što je zastupanje u vezi s određivanjem osobnog imena djeteta pravo roditelja, isto pravo imaju i posvojitelji, a što ObZ i posebno naglašava u čl. 198. st. 1. Isto tako, ObZ propisuje da posvojenik dobiva zajedničko prezime posvojitelja, a da će se u slučajevima kada posvojitelji nemaju zajedničko

37 Čl. 7. st. 3. ZOI-a: U slučaju nepostojanja suglasnosti drugog roditelja iz stavaka 1. i 2. ovoga članka, na spor roditelja primjenjuju se odredbe posebnog zakona kojima se uređuju obiteljski odnosi. Odluku nadležnog tijela roditelj će priložiti zahtjevu za promjenu osobnog imena djeteta. 
Doc. dr. sc. Nataša Lucić: Zastupanje u vezi s bitnim osobnim pravima djeteta

Zbornik radova Pravnog fakulteta u Splitu, god. 58, 3/2021, str. 815-840

prezime, prezime posvojeniku odrediti u skladu s posebnim zakonom (čl. 198. st. 2.). Jasno je da ovdje ObZ upućuje na ZOI, ali ZOI ne sadrži odredbe o određivanju osobnog imena posvojenika u situaciji kada posvojitelji nemaju zajedničko prezime, štoviše za određivanje osobnog imena posvojenom djetetu ZOI u potpunosti upućuje na obiteljsko zakonodavstvo. ${ }^{38} \mathrm{O}$ zaštiti najboljih interesa posvojenika u promjeni njegova osobnog imena brine centar za socijalnu skrb, pa ObZ tako propisuje da će ako centar za socijalnu skrb utvrdi da je to u njegovom interesu, posvojenik zadržati ime i prezime koje je imao prije zasnivanja posvojenja, ili svojem prezimenu dodati prezime posvojitelja (čl. 198. st. 2.).

Kada govorimo o sudjelovanju djeteta u odlučivanju o promjeni njegova osobnog imena važno je istaknuti da ZOI propisuje da je za promjenu osobnog imena maloljetnom djetetu starijem od deset godina potreban njegov pristanak. ${ }^{39}$ Dakle, roditelji ne mogu promijeniti osobno ime djeteta starijeg od deset godina ako se i samo dijete ne slaže s promjenom svog osobnog imena. Zanimljivo je da ObZ ne govori ništa o pristanku djeteta na promjenu osobnog imena koju iniciraju biološki roditelji, ali propisuje da je za promjenu osobnog imena posvojenika koji je navršio dvanaest godina života potreban njegov pristanak (čl. 198. st. 5.). Za pretpostaviti je da je ObZ slijedio istu dobnu granicu za davanje pristanka posvojenika za promjenu osobnog imena kao i za davanje pristanka na posvojenje ${ }^{40}$, međutim, u kontekstu sudjelovanja djeteta u promjeni njegova osobnog imena u obliku davanja pristanka kojim se takva promjena uvjetuje, ne bi trebalo činiti razliku u dobnoj granici djeteta ovisno o tome iniciraju li promjenu osobnog imena djeteta roditelji ili posvojitelji. ${ }^{41}$

38 Kod ovakve zakonske nedorečenosti uputno je slijediti sporazum posvojitelja oko osobnog imena posvojenika, pri čemu dijete može imati prezime jednog ili oba posvojitelja, a ako se posvojitelji koji nemaju isto prezime nisu sporazumjeli oko prezimena posvojenika, rješavanje pitanja osobnog imena posvojenika treba biti u nadležnosti centra za socijalnu skrb. Ovakav zaključak izveden je iz analogne primjene odredbi ZOI-a kojim se uređuje pitanje određivanja osobnog imena djeteta kada se o istom nisu sporazumjeli njegovi roditelji, ali i uzimajući u obzir da je provođenje samog postupka posvojenja u nadležnosti istoga tijela.

39 U Nizozemskoj je za promjenu osobnog imena djeteta potreban pristanak djeteta starijeg od dvanaest godina (vidi internetsku stranicu Justis Ministarstva pravosuđa i sigurnosti Nizozemske: https:// www.justis.nl/producten/naamswijziging/achternaam-minderjarige-wijzigen/index.aspx, pristupljeno 14. veljače 2021.); u Slovačkoj pristanak djeteta starijeg od petnaest godina (vidi Pavlekova, 2013, str. 69); u Ujedinjenom Kraljevstvu dijete starije od šesnaest godina može i samo inicirati promjenu svojega osobnog imena (vidi internetsku stranicu vlade Ujedinjenog Kraljevstva: https://www.gov.uk/changename-deed-poll/change-a-childs-name, pristupljeno 14. veljače 2021.).

Neki pravni sustavi i danas potpuno zanemaruju ulogu djeteta u postupku promjene osobnog imena, bez obzira na djetetovu dob, primjerice, iranski pravni sustav (vidi Mirshekari i Ketilate, 2020, str. 141).

40 Naime, sukladno čl. 191. st. 1. ObZ-a, za zasnivanje posvojenja djeteta koje je navršilo dvanaest godina života potreban je i njegov pristanak.

${ }_{41} \mathrm{ObZ}$, za razliku od ZOI-a, ne odvaja promjenu i određivanje osobnog imena posvojenika nego se u istoj odredbi (čl. 198.) referira na oboje podrazumijevajući zapravo pod pojmom "određivanje" promjenu osobnog imena posvojenika, jer posvojeniku je prije zasnivanja posvojenja osobno ime uglavnom već određeno (od strane bioloških roditelja ili centra za socijalnu skrb). 


\section{PROMJENA PREBIVALIŠTA/BORAVIŠTA DJETETA}

Kada govorimo o zaštiti djeteta kod promjene njegova mjesta stanovanja u izvannacionalnim okvirima, možemo reći da je ona uklopljena u sustav međunarodnih i europskih mehanizama koji stvaraju sponu između zaštite prava na slobodu kretanja i prava na obiteljski život. ${ }^{42}$ ESLJP je u više svojih odluka isticao neodvojivost prava na obiteljski život $\mathrm{s}$ djetetom i prava na kontakt $\mathrm{s}$ djetetom. ${ }^{43}$ Drugim riječima, kako to sažimaju Choudhry i Herring, stav je ESLJP da pravo odrasle osobe na obiteljski život s djetetom uključuje i pravo na kontakte s djetetom, te da isto tako, pravo djeteta na obiteljski život s odraslom osobom uključuje i pravo na kontakte s tom osobom (Choudhry i Herring, 2010, str. 243). Konkretno, vezano za kontakte roditelja i djeteta, u svojoj odluci u predmetu Kosmopoulou protiv Grčke ${ }^{44}$, primjerice, ESLJP izričito navodi da obostrano uživanje kontakata roditelja i djeteta "čini ključni element obiteljskog života." Osjetljivost zastupanja djeteta $u$ vezi s promjenom njegova prebivališta odnosno boravišta leži upravo u činjenici da ova promjena može znatno utjecati na ostvarivanje obiteljskoga života djeteta i drugog roditelja. ${ }^{45}$

Uzimajući u obzir sve učestalije prekide obiteljskih zajednica, te povećanu mobilnost europskih građana uzrokovanu različitim faktorima, Vijeće Europe je 11. veljače 2015. godine usvojilo Preporuku CM / Rec (2015) 4 o sprečavanju i rješavanju sporova oko preseljenja djece (dalje u tekstu: Preporuka). Ova Preporuka bi trebala pomoći u iznalaženju rješenja da se roditelja ili drugog nositelja roditeljske skrbi s kojim dijete živi odvrati od jednostranog preseljenja s djetetom i da se spriječi nezakonito preseljenje (Lowe, 2016, str. 116). Preporuka sadrži jedanaest načela, a primjenjuje se na situacije u kojima postoji neslaganje oko preseljenja djeteta unutar pojedine zemlje članice ili izvan nje, posebno gdje postoji rizik gubitka ili značajnijeg prekida kontakta djeteta s roditeljima ili drugim nositeljima roditeljske skrbi. U takvim situacijama, sukladno Načelu 1. Preporuke, nacionalnim bi zakonodavstvom kojim se regulira pitanje djetetova preseljenja trebalo:

a. osigurati dovoljan stupanj pravne sigurnosti za sprečavanje i rješavanje sporova;

b. pružiti dovoljnu fleksibilnost za uspješno rješavanje pojedinačnih sporova;

c. poticati postizanje sporazuma.

42 Kako navode Jastram i Newland, uz univerzalno uvažavanje obitelji kao temeljne društvene jedinice koja uživa posebnu zaštitu, važno je prepoznati da je obitelj skupina pojedinaca koji čine određenu "zajednicu", a kada članovi obitelji ne bi imali pravo na zajednički život, ne bi ni postojala "zajednica" koju treba poštovati ili štititi (Jastram i Newland, 2003).

43 Vidi, primjerice, Hokkanen protiv Finske, Zahtjev br. 19823/92, Odluka od 23. rujna 1994.; Sahin protiv Njemačke, Zahtjev br. 30943/96, Odluka od 8. srpnja 2003. itd.

44 Kosmopoulou protiv Grčke, Zahtjev br. 60457/00, Odluka od 5. veljače 2004.

45 O važnosti kontakata djeteta s oba roditelja i problemima kod ostvarivanja kontakata kada roditelji ne žive u obiteljskoj zajednici, je već široko raspravljeno u domaćoj literaturi. Vidi, primjerice, Rešetar, 2011. 
Kod postizanja sporazuma i rješavanja sporova u vezi s preseljenjem djeteta primarno se treba voditi računa o djetetovim najboljim interesima (Načelo 2.). Dijete treba imati pravo na informiranje i savjetovanje te na izražavanje svojih stavova o predloženom preseljenju, a djetetovom mišljenju treba dati odgovarajuću težinu u skladu s njegovom dobi i stupnjem zrelosti (Načelo 3.). Roditelji ili drugi nositelji roditeljske skrbi bi imati pravo bilo koji neriješeni spor o preseljenju djeteta podnijeti nadležnom tijelu na odlučivanje (Načelo 6.), ali bi svakako trebalo promovirati alternativne načine rješavanja sporova kako bi se postigli sporazumi o preseljenju djece (Načelo 5.). U nedostatku sporazuma, uobičajeno prebivalište djeteta ne bi se trebalo mijenjati bez odluke nadležnog tijela, osim u okolnostima predviđenim nacionalnim pravom (Načelo 7.).

Zakon o prebivalištu ${ }^{46}$ (dalje $u$ tekstu: ZP) prebivalište definira kao mjesto i adresu u Republici Hrvatskoj na kojoj se osoba trajno nastanila radi ostvarivanja svojih prava i obveza vezanih za životne interese kao što su obiteljski, profesionalni, ekonomski, socijalni, kulturni i drugi interesi (čl. 2. st. 1.), a boravište kao mjesto i adresu u Republici Hrvatskoj gdje osoba privremeno boravi, ali se na toj adresi nije trajno nastanila (čl. 2. st. 2.). Određivanje mjesta stanovanja djeteta pravo je njegovih roditelja. ${ }^{47}$ Zastupanje djeteta vezano za promjenu mjesta njegova prebivališta, odnosno boravišta, postaje osobito osjetljivo pravno pitanje u situacijama kada promjenu djetetova boravišta inicira samo jedan roditelj, upravo zbog implikacija koje takva promjena može imati na ostvarivanje prava na kontakte te ujedno i prava na obiteljski život između djeteta i drugog roditelja. Od tri vrste zastupanja koje ObZ izričito ubraja u zastupanja u vezi s bitnim osobnim pravima djeteta, možemo reći da se u praksi najčešće događa zastupanje u vezi s promjenom djetetova prebivališta odnosno boravišta. Dok se promjena djetetova osobnog imena pa i promjena vjerske pripadnosti u praksi relativno rijetko događaju, a i roditelji se oko ovih zastupanja djeteta rijetko spore, s porastom broja razvoda brakova, pa i prestanaka izvanbračnih zajednica u kojima su rođena zajednička djeca, rastu i prijepori roditelja oko mjesta djetetova stanovanja.

Jednako kao i kod drugih zastupanja u vezi s bitnim osobnim pravima djeteta, ObZ propisuje da je zastupanje u vezi s promjenom prebivališta odnosno boravišta djeteta valjano ako roditelj koji zastupa dijete ima pisanu suglasnost drugog roditelja koji ima pravo zastupati dijete, uz dvije iznimke (čl. 100. st. 3. i 4.):

- suglasnost nije potrebna ako preseljenje bitno ne utječe na ostvarivanje postojećih osobnih odnosa s drugim roditeljem, pod uvjetom da je roditelj s kojim dijete stanuje pribavio suglasnost centra za socijalnu skrb.

46 Zakon o prebivalištu (Narodne novine br. 144/12, 158/13, 115/14)

47 Pravo roditelja da određuju djetetovo mjesto stanovanja može biti ograničeno isključivo odlukom suda ili potrebom pribavljanja suglasnosti centra za socijalnu skrb (čl. 96. st. 3. ObZ-a). Roditelji imaju obvezu sporazumno odrediti mjesto stanovanja djeteta, a ako sami roditelji ne stanuju zajedno, dijete može imati mjesto stanovanja samo kod jednog od roditelja, s time da to ne može biti roditelj koji ne ostvaruje roditeljsku skrb o osobnim pravima djeteta ili je lišen prava na roditeljsku skrb (čl. 96. st. 2. i 4. ObZ-a). 
- suglasnost nije potrebna ako je prijava prebivališta, odnosno boravišta nužna radi zaštite prava i interesa djeteta, pod uvjetom da je roditelj s kojim dijete stanuje pribavio suglasnost centra za socijalnu skrb.

Ako se ne radi niti o jednoj od ove dvije iznimke, a roditelj koji zastupa dijete ne može pribaviti suglasnost drugog roditelja za promjenu prebivališta odnosno boravišta djeteta, sud će u izvanparničnom postupku na prijedlog djeteta ili roditelja odlučiti koji će od roditelja u toj stvari zastupati dijete radi zaštite dobrobiti djeteta. ${ }^{48}$

ZP u čl. 5. st. 2. do 5. regulira postupak prijave i odjave prebivališta i boravišta djeteta. Propisuje da prijave za maloljetne osobe podnose roditelji (čl. 5. st. 2.), a da se kada roditelji maloljetne osobe imaju prijavljeno prebivalište ili boravište na različitim adresama, prebivalište ili boravište maloljetne osobe prijavljuje na adresi jednog roditelja, uz suglasnost drugog (čl. 5. st. 3.). U tom je dijelu ZP u suglasju s ObZ-om. Međutim, ZP nadalje propisuje da ako roditelji maloljetne osobe ne žive u obiteljskoj zajednici, zahtjev podnosi roditelj s kojim maloljetna osoba živi na temelju odluke nadležnog tijela, te da se prebivalište maloljetne osobe prijavljuje na adresi tog roditelja (čl. 5. st. 4.). U slučajevima kada roditelji maloljetne osobe ne žive u obiteljskoj zajednici, a nije donesena odluka nadležnog tijela o tome s kojim će roditeljem maloljetna osoba živjeti, prebivalište maloljetne osobe prijavljuje se na adresi roditelja s kojim maloljetnik živi, uz suglasnost centra za socijalnu skrb (čl. 5. st. 5.). Moglo bi se, tako, dogoditi da ako je dijete rođeno u izvanbračnoj zajednici sud nije donio odluku o tome s kojim će roditeljem dijete živjeti zbog neformalnog prestanka izvanbračne zajednice. U tom slučaju ne bi bilo u skladu s ObZ-om da jedan roditelj uz suglasnost centra za socijalnu skrb prijavljuje prebivalište odnosno boravište djeteta. Roditelji bi trebali sastaviti plan o zajedničkoj roditeljskoj skrbi, a ako se ne bi mogli suglasiti oko pitanja koja se njime reguliraju, tada bi o pitanjima bitnim za dijete trebao odlučiti sud. I roditelji koji nisu formalno razveli brak, a ne žive u obiteljskoj zajednici ne bi trebali biti u mogućnosti da jedan od njih bez suglasnosti drugog uz odobrenje centra za socijalnu skrb mijenja prebivalište djeteta. Ovdje, također, treba primijeniti odgovarajuće odredbe ObZ-a koji propisuje da je za promjenu djetetova prebivališta potrebna suglasnost oba roditelja ${ }^{49}$, a da je $u$ nedostatku takve suglasnosti odluka o zastupanju djeteta u tom pravnom pitanju u nadležnosti suda.

48 Prama Parkinson i Cashmore kod promjene prebivališta djeteta s jednim od roditelja nužno je u svakom pojedinom slučaju razmotriti tri sljedeća ključna pitanja (Parkinson i Cashmore, 2015, str. 34):

1. Koliko je blizak odnos između drugog roditelja i djeteta i koliko je taj odnos djetetu razvojno važan?

2. Ako se preseljenje dopusti, koliko su izvedivi prijedlozi za kontakte s drugim roditeljem?

3. Ako je odnos između djeteta i drugog roditelja razvojno važan za dijete i vjerojatno će se umanjiti ako se preseljenje dopusti:

(a) Koji su izvedive alternative?

(b) Je li preseljenje manje štetna alternativa?

49 Uz dvije iznimke predviđene u čl. 100. st. 3. i 4., o kojima je prethodno raspravljeno. 


\section{IZBOR ILI PROMJENA VJERSKE PRIPADNOSTI DJETETA}

Ustav RH, kao i ustavi mnogih drugih država, jamči slobodu savjesti i vjeroispovijedi i slobodno javno očitovanje vjere ili drugog uvjerenja (čl. 40) ${ }^{50}$ Pravo na slobodu vjeroispovijesti kao temeljno ljudsko pravo zaštićeno je i odredbama mnogih međunarodnih ugovora ${ }^{51}$, pri čemu je u kontekstu ovoga prava kao prava djeteta ${ }^{52}$ posebno važno istaknuti odredbu čl. 14. st. 1. KPD-a koja propisuje da će države stranke priznati djetetu pravo na slobodu misli, savjesti $i$ vjere. Dakle, KPD određuje dijete kao titulara ovoga prava što ukazuje na nužnost razumijevanja kako, unutar ljudskih prava, djetetu dotično ljudsko pravo pripada inherentno njegovu dostojanstvu kao ljudske osobe (Hlača i Popović, 2009, str. 280). ${ }^{53}$ U čl. 14. st. 3. KPD propisuje da djetetova sloboda izražavanja vjere ili uvjerenja može biti podvrgnuta isključivo zakonom određenim ograničenjima koja su prijeko potrebna radi zaštite javne sigurnosti, zdravlja ili morala ili temeljnih prava $i$ sloboda drugih. Ova odredba sadrži klasičnu ograničavajuću klauzulu koja je u sustavu ljudskih prava uobičajen popratni dio uz propisivanje slobode savjesti i vjeroispovijesti u međunarodnim ugovorima (tako i Hlača i Popović, 2009, str. 283). Obveza poštivanja odgovornosti, prava i dužnosti roditelja kod usmjeravanja i vođenja djeteta u ostvarenju njegovih prava koja je propisana u čl. 5. KPD-a, vezano uz ostvarenje prava djeteta na slobodu misli, savjesti i vjere u čl. 14. st. 2. KPD-a je još jednom ponovljena: Države stranke poštivat će prava i dužnosti roditelja $i$, u određenim slučajevima, zakonskih skrbnika, u svezi s pružanjem pomoći djetetu u korištenju svojih prava na način koji je u skladu s njegovim razvojnim sposobnostima.

Roditelj kao zastupnik djeteta u ostvarenju njegova prava na slobodu vjeroispovijesti u najranijoj dobi djeteta može odrediti njegovu vjersku pripadnost i kroz svakodnevni obiteljski život utječe na razvoj njegova vjerskog identiteta. ${ }^{54}$ Deklaracija o ukidanju svih oblika nesnošljivosti i diskriminacije na temelju vjere i uvjerenja u čl. 5. st. 1. propisuje da roditelji imaju pravo organizirati život u obitelji u skladu s njihovom religijom ili vjerovanjem, imajući na umu moralni odgoj u

50 Odredbom čl. 17. st. 3. Ustav RH propisuje da se niti u slučaju neposredne opasnosti za opstanak države ne može ograničiti primjena njegovih odredbi o pravu na život, zabrani mučenja, surovog ili ponižavajućeg postupanja ili kažnjavanja, o pravnoj određenosti kažnjivih djela i kazni, te o slobodi misli, savjesti i vjeroispovijedi.

51 Vidi, primjerice, čl. 18. Međunarodnog pakta o građanskim i političkim pravima; čl. 1. Deklaracije o ukidanju svih oblika nesnošljivosti i diskriminacije na temelju vjere i uvjerenja; čl. 9. EKLJP; čl. 10. Povelje Europske unije o temeljnim pravima (Službeni list Europske unije, 2007/C 303/01).

52 Znanstvene spoznaje u području psihologije, duhovnosti i sociologije upućuju na religioznu dimenziju djeteta koje pravo ne bi smjelo ignorirati (Langlaude, 2007, str. 3).

53 O pravu djeteta na slobodu vjeroispovijedi u svjetlu postojećeg normativnog okvira i prakse na međunarodnoj, europskoj i nacionalnoj razini, te prijedloge mjera koje mogu pridonijeti potpunijoj realizaciji ovog djetetova prava vidi u Radina, 2018. Vidi i usporednopravnu analizu prava djeteta na slobodu vjeroispovijedi i prava roditelja na odgoj djece prema vlastitim vjerskim uvjerenjima u Hlača, 2014.

54 O pravima i dužnostima bračnih drugova koja u odnosu na djecu propisuju norme vjerskih organizacija vidi u Čović, 2020. 
kojem smatraju da bi trebalo podizati dijete. Međutim, osim kroz obiteljski život dijete vjerske spoznaje stječe i kroz obrazovanje gdje se uloga roditelja, također, snažno uvažava. Potrebno je, naime, postići sklad između vjerske naobrazbe djeteta i osobnih uvjerenja roditelja, na što obvezuje više međunarodnih dokumenata. Tako, primjerice, Međunarodni pakt o građanskim i političkim pravima u čl. 18. st. 4. propisuje da će države stranke poštivati slobodu roditelja $i$, gdje postoji takav slučaj, zakonskih skrbnika da svojoj djeci osiguraju vjerski i moralni odgoj u skladu sa svojim osobnim uvjerenjima. Deklaracija o ukidanju svih oblika nesnošljivosti i diskriminacije na temelju vjere i uvjerenja u čl. 5. st. 2. propisuje da će svako dijete uživati pravo na pristup obrazovanju u vezi s religijom ili vjerovanjem $u$ skladu sa željama njegovih roditelja ili, zavisno od slučaja, zakonskih skrbnika, $i$ neće biti primoran poučavanju religije ili vjerovanja protivno želji svojih roditelja ili zakonskih skrbnika, vodeći se principom najboljeg interesa djeteta. Slično se utvrđuje i u čl. 2. Prvog protokola uz EKLJP: Nikome neće biti uskraćeno pravo na obrazovanje. U obavljanju svojih funkcija povezanih s odgojem i poučavanjem država će poštovati pravo roditelja da osiguraju odgoj i poučavanje u skladu sa svojim vjerskim i filozofskim uvjerenjima. Povelja EU u čl. 14. st. 3. propisuje da se sloboda osnivanja obrazovnih ustanova, uz poštovanje demokratskih načela, te pravo roditelja da svojoj djeci osiguraju obrazovanje i poučavanje u skladu sa svojim vjerskim, filozofskim i pedagoškim uvjerenjima, poštuju u skladu s nacionalnim zakonima koji uređuju ostvarivanje takve slobode i prava.

I ESLJP je u svojoj praksi ${ }^{55}$ isticao važnost poštivanja vjerskih uvjerenja roditelja u organizaciji obrazovnog sustava. Tako je, primjerice, u slučaju Kjeldsen, Busk Madsen i Pedersen protiv Danske ${ }^{56}$ ESLJP izrazio stajalište da državi, koja organizira obrazovni sustav, nije dopušteno razvijati aktivnosti koje bi značile indoktriniranje učenika u pogledu religijskog ili moralnog svjetonazora, suprotno uvjerenju njihovih roditelja. Predmet Grzelak protiv Poljske ${ }^{57}$ odnosi se na slučaj u kojemu podnositelj zahtjeva, sukladno želji svojih roditelja deklariranih agnostika, nije pohađao vjeronauk u školi, a nije mogao pohađati ni etiku obzirom da je za ovaj predmet bio zainteresiran premali broj učenika pa nastava iz etike nije bila niti organizirana. Na svjedodžbama mu je umjesto ocjene za "vjeronauk/etiku" stajala ravna crta. Prema ESLJP-u, ovo ulazi u opseg negativnog aspekta slobode

55 ESLJP je odigrao važnu ulogu u promicanju i zaštiti prava na slobodu mišljenja, savjesti i vjeroispovijesti uopće. U predmetu Bayatyan protiv Armenije (zahtjev br. 23459/03, presuda od 7. srpnja 2011.) ESLJP je u toč. 118. označio okvir i značenje ovoga prava:

"Sud ponavlja da je sloboda mišljenja, savjesti i vjeroispovijesti, zajamčena člankom 9. Konvencije jedan od temelja 'demokratskog društva' u smislu Konvencije. Ta sloboda, u svojoj vjerskoj dimenziji, jedan je od najživotnijih elemenata koji stvaraju identitet vjernika i njihove koncepcije života, ali je također dragocjeno sredstvo ateista, agnostika, skeptika i onih koji prema vjeri nemaju nikakav odnos. O njoj ovisi pluralizam, neodvojiv dio demokratskog društva, kojeg se ostvarenje skupo plaćalo tijekom stoljeća. Ta sloboda obuhvaća slobodu prihvatiti ili ne prihvatiti vjerska uvjerenja (i prakticirati ili ne prakticirati vjeru..."

56 Kjeldsen, Busk Madsen i Pedersen protiv Danske, Zahtjev br. 5095/71; 5920/72; 5926/72, Odluka od 7. prosinca 1976.

57 Grzelak protiv Poljske, Zahtjev br. 7710/02, Odluka od 15. lipnja 2010. 
mišljenja, savjesti i vjeroispovijedi jer bi svjedodžbe mogle ukazivati na vjersku neopredijeljenost što predstavlja oblik neželjene stigmatizacije.

Čolaković razložno upozorava kako pravo roditelja da biraju svoju vjersku pripadnost i određuju vjersku pripadnost svoga djeteta u određenim slučajevima može doći u koliziju s pravom djeteta na tjelesni integritet, odnosno s ostvarenjem njegovog prava na samoodređenje o životu i zdravlju (Čolaković, 2014, str. 70). Ističe kako se sukob između prava roditelja na slobodu vjeroispovijesti i prava djeteta na tjelesni integritet i samoodređenje o vlastitom životu i zdravlju u praksi javlja u situacijama kada roditelji inzistirajući na svojim vjerskim uvjerenjima djetetu uskraćuju pravo na liječenje, čime ne samo da krše njegovo pravo na samoodređenje nego u opasnost dovode djetetovo život i zdravlje, ${ }^{58}$ te u situacijama kada roditelji iz vjerskih uvjerenja podvrgavaju dijete određenim medicinskim zahvatima koji nisu medicinski indicirani ${ }^{59}$ čime načelno ne ugrožavaju djetetov život i zdravlje, ali zadiru u njegovo pravo na samoodređenje.

Međutim, neupitno je da kada nastupaju kao djetetovi zakonski zastupnici u zaštiti njegovih osobnih prava, roditelji ne mogu i ne smiju postupati suprotno djetetovim najboljim interesima, neovisno o vlastitim uvjerenjima. Zaštita života i zdravlja djeteta ima primat nad roditeljskim pravima na prakticiranje vjere. Deklaracijom o ukidanju svih oblika diskriminacije na temelju vjere i uvjerenja je u čl. 5. st. 5. i izričito propisano da prakticiranje religije ili vjerovanja u kojem se dijete odgaja ne smije biti štetno za djetetovo fizičko ili mentalno zdravlje ili djetetov puni razvoj. Stoga niti nema osnove da se kod ostvarivanja prava na zastupanje djeteta, kao i kod ostvarivanja bilo kojeg drugog prava ili dužnosti koje čini sadržaj roditeljske skrbi, jednog roditelja dovodi u nepovoljniji položaj u odnosu na drugog, zbog straha da će njegova vjerska uvjerenja možebitno ugroziti prava i interese djeteta.

Da određena vjerska pripadnost roditelja ne smije biti nepovoljan faktor kod odlučivanja o roditeljskoj skrbi u svojoj je praksi isticao i ESLJP. U predmetu Hoffman protiv Austrije ${ }^{60}$ podnositeljica zahtjeva, njen bivši suprug i dvoje zajedničke djece živjeli su kao rimokatolici do razvoda braka, a nakon razvoda podnositeljica zahtjeva je prešla u vjersku organizaciju Jehovinih svjedoka. Prigovorila je da joj je uskraćena roditeljska skrb na temelju njezinih vjerskih uvjerenja protivno čl. 8 . EKLJP (pravo na poštivanje obiteljskog života), čl. 9. EKLJP (pravo na slobodu vjeroispovijedi), čl. 2. Protokola br. 1 (pravo na obrazovanje svoje djece u skladu s vlastitim vjerskim uvjerenjima) i čl. 14. EKLJP (zabrana diskriminacije na temelju vjere). Naime, Vrhovni je sud Austrije kod odlučivanja o roditeljskoj skrbi presudio u korist oca s obrazloženjem da u suprotnom postoji opasnost od mogućih negativnih

58 Kao primjer Čolaković, između ostaloga, navodi odbijanje tretmana kemoterapije i radioterapije kao metoda u liječenju djeteta oboljelog od karcinoma, premda mu one daju veće šanse za preživljavanje; odbijanje redovitog cijepljenja djeteta; liječenje djeteta isključivo molitvama i vjerom, a ne konvencionalnom medicinom; nepristajanje roditelja na transfuziju krvi njihovom djetetu, čak i kada mu je život ugrožen; uskraćivanje suglasnosti na davanje kontraceptivnih sredstava ili pobačaj maloljetnice (Čolaković, 2014, str. 71)

59 Kao primjer za ovo Čolaković navodi obrezivanje - cirkumciziju muške djece.

60 Hoffman protiv Austrije, Zahtjev br. 12875/87, Odluka od 23. lipnja 1993. 
učinaka koji proizlaze iz povezanosti s određenom vjerskom manjinom na društveni život djece, opasnosti potpunog odbijanja transfuzije krvi za djecu, izostanka obilježavanja blagdana Božića i Uskrsa koji slavi većina austrijskog stanovništva i sl. ESLJP je u ovom predmetu izrazio stajalište kako se kod donošenja odluke o roditeljskoj skrbi u slučaju razvoda braka roditelje ne smije različito tretirati na religijskoj osnovi. ${ }^{61}$

Promatrano u okvirima nacionalnog prava, jedino se odredbama obiteljskog zakonodavstva o odgoju djeteta ${ }^{62}$ i zastupanju djeteta u bitnim osobnim pravima reguliraju pravni odnosi roditelja i djece vezano uz djetetovu vjersku pripadnost. Prema tome, dok vezano za zastupanja u drugim bitnim osobnim pravima djeteta postoje određene kolizije odredbi ObZ-a i drugih relevantnih propisa, istih kolizija nema kada je u pitanju zastupanje u vezi s izborom ili promjenom vjerske pripadnosti djeteta. Nacionalno se pravo niti u jednom propisu eksplicite ne dotiče ni uloge roditelja u vjerskoj naobrazbi djeteta. Zakon o odgoju i obrazovanju u osnovnoj i srednjoj školi ${ }^{63}$ kao jedan od ciljeva odgoja i obrazovanja u školskim ustanovama navodi i odgoj i obrazovanje učenika u skladu s općim kulturnim i civilizacijskim vrijednostima, ljudskim pravima i pravima djece (čl. 4. st. 1. toč. 3.), pri čemu se kod promicanja ovih odgojnih vrijednosti uvažava pravo roditelja da samostalno odlučuju o odgoju djece (čl. 4. st. 2. toč. 9.), ali ni u ovom se zakonu nigdje izričito ne navodi obveza poštivanja vjerskih uvjerenja roditelja u organizaciji obrazovnog sustava. ${ }^{64}$

Dok djetetovo ime ako je dijete starije od deset godina nije moguće promijeniti bez njegova pristanka, promjena religijske pripadnosti djeteta nije uvjetovana njegovim pristankom, obzirom da promjena religijske pripadnosti niti ne podrazumijeva neku vrstu formalnog postupanja. ${ }^{65}$ To ne znači da ne postoji obveza dijete uključiti u donošenje odluka koje imaju implikacije na njegov vjerski identitet, sukladno dobi i zrelosti djeteta, odnosno sposobnosti njegova razumijevanja vlastitoga religijskog identiteta. Prema Elkidu, generalno se može reći kako djeca u dobi od pet do sedam godina obično imaju samo načelna shvaćanja svojeg religijskog identiteta,

${ }_{61}$ U tom smislu vidi i odluke u predmetima Palau-Martinez protiv Francuske, Zahtjev br. 64927/01, Odluka od 16. prosinca 2003.; te Ismailova protiv Rusije, Zahtjev br. 37614/02, Odluka od 29. prosinca 2007.). Detaljna analiza sve tri odluke u: Riel, 2010, dostupno na: http://arno.uvt.nl/show.cgi?fid=122325 (pristupljeno: 14. veljače 2021.).

${ }^{62}$ ObZ obvezuje roditelje da djetetu osiguraju odgoj koji je u skladu s njegovom dobi i zrelošću te s pravom djeteta na slobodu savjesti, vjerskog i drugog uvjerenja (čl. 94. st. 1.).

63 Zakon o odgoju i obrazovanju u osnovnoj i srednjoj školi (Narodne novine br. 87/08, 86/09, 92/10, 105/10, 90/11, 5/12, 16/12, 86/12, 126/12, 94/13, 152/14, 07/17, 68/18, 98/19, 64/20, 133/20)

64 Međutim, kako razložno navodi Hrabar, interakcija odgoja i obrazovanja djece je nužna, logična, i samorazumljiva. Prema tome, obzirom na primarnu ulogu roditelja kao odgajatelja te važnost i značenje načelne autonomije obitelji za svako dijete, logično je zaključiti da roditelji imaju primarnu odgajateljsku funkciju, a da u obrazovnome procesu moraju sudjelovati (Hrabar, 2018, str. 322 i 323). U skladu s navedenim, dalo bi se zaključiti da, iako ne eksplicite, Zakon o odgoju i obrazovanju u osnovnoj i srednjoj školi (u korelaciji s odredbama ObZ-a o pravima i dužnostima roditelja u odgoju djeteta), ipak uvažava ulogu roditelja i u vjerskoj naobrazbi djeteta.

65 Pojedina vjerska organizacija možda i zahtijeva neki oblik formalnog upisa djeteta u vjersku zajednicu, ali to je s građanskopravnog aspekta potpuno irelevantno. 
da do značajnijeg progresa u konceptualizaciji religijskog identiteta dolazi u dobi od sedam do devet godina, te da su najčešće u dobi od deset do dvanaest godina djeca spremnija na refleksiju religijskih shvaćanja i prihvaćanje apstraktnih vidova religije (Elkid prema Langlaude, 2007, str. 4).

U situacijama kada postoji neslaganje djeteta starijeg od četrnaest godina s roditeljima oko zastupanja u izboru i promjeni vjerske pripadnosti, pravni položaj djeteta dodatno osnažuje i ObZ-om propisana mogućnost samostalnog pokretanja sudskog postupka pred nadležnim tijelima u vezi s ostvarivanjem njegovih prava i interesa (čl. 87., a u svezi s čl. 359.). ${ }^{6}$ Ipak, kako naglašavaju Hlača i Popović, uzimajući u obzir osjetljivost ovog područja obiteljskog odnosa roditelja i djeteta, valja imati na umu da su vrlo male mogućnosti da se sukob roditelja i djeteta oko vjerskog ili drugog uvjerenja javlja kao izolirana pojava, nego se on najčešce događa u sklopu neslaganja i oko drugih komponenata njihova obiteljskog odnosa (Hlača i Popović, 2009, str. 296). Isto tako, vjerojatnije je da će se neslaganje roditelja i djeteta oko djetetove vjerske pripadnosti vezati uz neslaganje samih roditelja oko ovoga pitanja, nego djeteta sa oba roditelja. ${ }^{67}$ Kada postoji neslaganje roditelja oko vjerske pripadnosti djeteta, dijete se u ObZ-u izričito navodi kao ovlaštenik za podnošenje prijedloga za donošenje odluke suda u izvanparničnom postupku o tome koji će od roditelja u toj stvari zastupati dijete (čl. 109. st. 1.). U svakom slučaju, kada postoji nesuglasje roditelja i djeteta oko djetetove vjerske pripadnosti, bilo kao izolirana ili pojava u sklopu nesuglasja oko više segmenata njihova (obiteljsko) pravnog odnosa i neovisno o tome postoji li istovremeno i nesuglasje samih roditelja oko istog pitanja, važno je da se zakonskim mehanizmima za njegovo rješavanje uvažava uloga djeteta u zaštiti i promicanju vlastitog prava na slobodu vjeroispovijedi, sukladno djetetovoj dobi i zrelosti i naravno, djetetovim najboljim interesima.

\section{ULOGA SKRBNIKA KOD ZASTUPANJA U VEZI S BITNIM OSOBNIM PRAVIMA DJETETA}

U nedostatku odgovarajuće roditeljske skrbi, djetetu štićeniku se skrbništvom nadomješta roditeljska skrb. ${ }^{68}$ Centar za socijalnu skrb je nadležno tijelo za donošenje rješenja o stavljanju djeteta pod skrbništvo i imenovanje skrbnika. Jednako kao i

${ }^{66}$ O mogućnosti djeteta da (samostalno) pokreće sudske postupke radi ostvarenja svojih prava, kao i o procesnopravnom položaju djeteta u obiteljskom zakonodavstvu uopće vidi u Šago, 2017 i Aras, 2014.

${ }_{67}$ Teško da uvrštavanje promjene djetetove vjeroispovijesti u odluke o "bitnom osobnom pravu djeteta" uopće može potaknuti sudske postupke upravo jer je riječ o pitanju koje se rješava više načinom života i (ne)ispovijedanjem vjeroispovijesti, vrlo rijetko promjenom vjeroispovijesti formalnim upisom djeteta u neku vjersku zajednicu (Korać Graovac, 2017, str. 63).

68 Sukladno čl. 224. ObZ-a skrbnik se imenuje djetetu čiji su roditelji umrli, nestali, nepoznati ili su najmanje mjesec dana nepoznatog boravišta; lišeni prava na roditeljsku skrb; lišeni poslovne sposobnosti u dijelu koji ih onemogućava u ostvarivanju roditeljske skrbi; maloljetni, a nisu stekli poslovnu sposobnost sklapanjem braka; odsutni ili spriječeni i nisu u mogućnosti brinuti se o svojem djetetu, a ostvarivanje roditeljske skrbi nisu povjerili osobi koja ispunjava uvjete za skrbnika; dali pristanak za posvojenje djeteta. 
roditelj, skrbnik djeteta dužan je savjesno se brinuti o osobnim i imovinskim pravima i obvezama djeteta, a posebno o zdravlju djeteta, njegovom odgoju i obrazovanju.

Kao što je to slučaj i kada dijete u vezi s njegovim bitnim (osobnim) pravima zastupa roditelj, zastupanje djeteta od strane skrbnika u ovom području je također regulirano drugačije nego zastupanje u donošenju ostalih odluka u vezi s djetetom. U tom smislu, važno je prije svega istaknuti da sukladno čl. 228. ObZ-a skrbnik ne može bez prethodnog odobrenja centra za socijalnu poduzimati važnije mjere u pogledu osobe djeteta ${ }^{69}$, primjerice, u pogledu zdravlja i izjava o osobnom stanju. Iako to u zakonu nije izričito navedeno, važnijim mjerama u smislu ove odredbe se svakako ima smatrati i promjena djetetova osobnog imena, prebivališta ili boravišta djeteta, te izbor i promjena djetetove vjerske pripadnosti. ${ }^{70}$ Osim toga, $\mathrm{i}$ ZOI propisuje da je skrbniku za određivanje (čl. 3. st. 4.), kao i za promjenu (čl. 7. st. 1.) osobnog imena djeteta potrebna suglasnost centra za socijalnu skrb. Međutim, proturječnost s obiteljskim zakonodavstvom postoji u dijelu u kojem se u ZOI-u navodi kada uopće skrbnik može odrediti osobno ime djetetu, pa se tako, između ostaloga, navodi da će skrbnik uz suglasnost centra za socijalnu skrb odrediti osobno ime djetetu kada su roditelji potpuno lišeni poslovne sposobnosti ili je odlukom o djelomičnom lišenju poslovne sposobnosti određeno da ne mogu poduzimati radnje koje se tiču osobnih stanja. ${ }^{71}$ Naime, iako je još prije više od pet godina stupanjem na snagu trenutno važećeg ObZ-a ukinuta mogućnost potpunog lišenja poslovne sposobnosti, mnogi se propisi, pa tako i ZOI, još uvijek nisu uskladili s ovom vrlo značajnom promjenom u nacionalnom pravu.

I dok se ZOI-om dosta detaljno regulira pitanje zastupanja djeteta u određivanju i promjeni osobnog imena djeteta koje nema odgovarajuću roditeljsku skrb odnosno kada roditelji nemaju pravo i dužnost zastupanja djeteta, ZP ne govori puno o prijavi prebivališta i boravišta djeteta u istoj situaciji. U čl. 5. st. 2. ZP-a se samo navodi da prijave za maloljetne osobe podnose roditelji, odnosno skrbnici bez bilo kakve posebne upute na postupak prijave prebivališta i boravišta djeteta od strane skrbnika koji bi se razlikovao od istog postupka kada ga iniciraju roditelji.

Što se tiče uvažavanja želja i mišljenja djeteta kod zastupanja od strane skrbnika u vezi s njegovim bitnim osobnim pravima, važno je naglasiti da i u okvirima pravne regulacije instituta skrbništva za djecu, ObZ izričito obvezuje da se dijete informira o svim važnim okolnostima koje se tiču njegovih prava i interesa, da mu se pruži savjet i omogući izražavanje mišljenja kao i da ga se informira o mogućim

69 Kao ni važnije mjere u pogledu imovine djeteta.

70 U čl. 259. kojim se utvrđuje za poduzimanje kojih je važnijih mjera u pogledu štićenika koji je lišen poslovne sposobnosti, dakle punoljetnog štićenika, skrbniku potrebno prethodno odobrenje centra za socijalnu skrb, u st. 2. se, pak, izričito navodi da se važnijim mjerama između ostaloga smatra i promjena prebivališta ili boravišta, te promjena osobnog imena.

71 Osim toga, ako roditelji djeteta nisu živi, ako su proglašeni umrlim, nije im poznati prebivalište ili su lišeni roditeljske skrbi (čl. 3. st. 4.).

Isto tako, vezano uz suglasnost drugog roditelja za promjenu osobnog imena djeteta ZOI propisuje da suglasnost nije potrebna, između ostaloga, kada je drugi roditelj potpuno lišen poslovne sposobnosti ili je odlukom o djelomičnom lišenju poslovne sposobnosti određeno da ne može poduzimati radnje koje se tiču osobnih stanja (čl. 7. st. 4.). 
Doc. dr. sc. Nataša Lucić: Zastupanje u vezi s bitnim osobnim pravima djeteta

Zbornik radova Pravnog fakulteta u Splitu, god. 58, 3/2021, str. 815-840

posljedicama poštivanja njegova mišljenja (čl. 230.). ${ }^{72} \mathrm{U}$ tom smislu, pravni odnos skrbnika i djeteta kod zastupanja u vezi s bitnim osobnim pravima djeteta je sličan pravnom odnosu roditelja i djeteta, pa je i skrbnik obvezan uvažavati ulogu djeteta kod ovih zastupanja na jednak način kao što bi to bio dužan činiti roditelj kada bi dijete imalo odgovarajuću roditeljsku skrb. ${ }^{73}$

\section{ZAKLJUČAK}

Sveobuhvatna analiza pravnog uređenja zastupanja djeteta u vezi s bitnim osobnim pravima zahtjeva pristup kojim će se izaći daleko izvan okvira obiteljskog zakonodavstva. Osobno ime, prebivalište odnosno boravište, te vjerska pripadnost djeteta predmet su regulacije mnogih međunarodnih i europskih dokumenata, a i u nacionalnim su okvirima ova pravna pitanja regulirana kroz nekoliko različitih propisa. Posljedično, kako bi analiza rezultirala objektivnom ocjenom pravnog stanja u području zakonske regulacije zastupanja djeteta u vezi s bitnim osobnim pravima, važno je ispitati usklađenost obiteljskog zakonodavstva s relevantnim propisima iz drugih pravnih područja.

I dok se generalno može zaključiti kako je u području zastupanja djeteta u vezi s bitnim osobnim pravima naše zakonodavstvo usklađeno s relevantnim supranacionalnim standardima u ovome pravnom području, u nacionalnim okvirima postoje i sadržajne i terminološke neusklađenosti među relevantnim propisima. Naime, trenutno je važeći ObZ kada je 2015. godine stupio na snagu uveo dosta velike promjene u domaće obiteljsko zakonodavstvo uopće, pa tako i u područje zastupanja djeteta. Uzimajući u obzir povezanost obiteljskog s drugim granama prava, a na koju upućuje i predmetna pravna problematika, bilo je nužno uskladiti određene propise s promjenama koje je uveo ObZ, ali to se usklađivanje, barem kada govorimo o zastupanju u vezi s bitnim osobnim pravima djeteta, iz nekoga razloga ipak nije dogodilo. Stoviše, premda je od stupanja na snagu ObZ-a proteklo već više od pet godina, ove se zakonske neujednačenosti, bez obzira na osjetljivost problematike u koju zadiru, i dalje sustavno zanemaruje.

Iako bi se o mogućim budućim promjenama pravne regulacije zastupanja u vezi s bitnim osobnim pravima djeteta moglo i daleko šire raspravljati, ovdje se upućuje na nekoliko ključnih de lege ferenda promjena nužnih za postizanje bolje usklađenosti među nacionalnim propisima. Najprije, nužno je uskladiti ZOI s obiteljskim zakonodavstvom u smislu izjednačavanja pravnog položaja roditelja koji ostvaruju zajedničku roditeljsku skrb, neovisno o tome je li pravni

$72 \mathrm{ObZ}$, isto tako propisuje da je prije poduzimanja mjera zaštite osobe (maloljetnog ili punoljetnog) štićenika, kao i njegovih imovinskih interesa, skrbnik uvijek obvezan razmotriti, te ako to nije u suprotnosti s njegovom dobrobiti, uzeti u obzir mišljenje, želje i osjećaje štićenika (čl. 252. st. 2.).

73 Kada govorimo konkretno o promjeni osobnog imena djeteta, važno je naglasiti da obveza pribavljanja suglasnosti djeteta starijeg od deset godina za promjenu osobnog imena koja je izričito propisana čl. 7. st. 5. ZOI-a postoji neovisno zastupa li dijete kod promjene osobnog imena roditelj, ili u nedostatku odgovarajuće roditeljske skrbi, djetetov skrbnik. 
temelj zajedničke roditeljske skrbi život u braku, izvanbračnoj zajednici ili pisani sporazum roditelja o zajedničkoj roditeljskoj skrbi, te propisati postupak promjene osobnog imena djeteta koji će biti prilagođen standardima ravnopravnog roditeljstva na kojima se temelji naše obiteljsko zakonodavstvo. Nadalje, vrlo je važno uskladiti ZP s ObZ-om u dijelu u kojim regulira prijavu djetetova prebivališta kada roditelji ne žive u obiteljskoj zajednici. Prijava prebivališta u nedostatku sudske odluke s kojim će roditeljem dijete živjeti, ne može biti pravo jednog roditelja kojeg taj roditelj ostvaruje uz suglasnost centra za socijalnu skrb. I ovdje treba voditi računa o odredbama ObZ-a kojima se regulira način ostvarivanja roditeljske skrbi ako roditelji trajno ne žive u obiteljskoj zajednici, te posljedično i zastupanju djeteta $\mathrm{u}$ vezi s bitnim osobnim pravima u takvim okolnostima.

$\mathrm{Na}$ kraju se upućuje i na važnost provođenja daljnjih istraživanja u ovom području. Osobito je važno ispitati u kojoj mjeri neujednačeni propisi uzrokuju neujednačena postupanja kod njihove primjene u pravnoj praksi, te imaju li i kakve implikacije eventualna neujednačena postupanja zakonskih zastupnika i nadležnih upravnih tijela na provođenje sudskih postupaka u vezi s bitnim osobnim pravima djeteta.

\section{LITERATURA}

\section{Knjige, znanstveni i stručni članci}

1. Aras, S. (2014). Položaj djeteta u postupku prema novom Obiteljskom zakonu, u: ur. Barbić, J., Novo uređenje obiteljskih sudskih postupaka, Zagreb: Hrvatska akademija znanosti i umjetnosti, 35-65.

2. Arts, K. (2019). Children's Rights and Sustainable Development Goals, u: ur. Kilkelly, U. i Liefaard, T. International Human Rights of Children. Springer: Singapore, 3-29.

3. Choudhry, S. i Herring, J. (2010). European Human Rights and Family Law. Oxford, Portland, Oregon: Hart Publishing.

4. Čolaković, M. (2014). Religijsko opredjeljenje roditelja vs. najbolji interes djeteta u ostvarenju njegovog prava na tjelesni integritet, Zbornik radova sa skupa Porodično pravo - najbolji interes djeteta u zakonodavstvu i praksi, Pravni fakultet u Mostaru, 67-82.

5. Čović, A. (2020). Porodičnopravni aspekti verskih brakova. Beograd: Institut za uporedno pravo.

6. Daly, A. (2018). Children, autonomy and the courts: beyond the right to be heard. Leiden/Boston: Brill.

7. Doek, J. (2019). The Human Rights of Children: An Introduction, u: ur. Kilkelly, U. i Liefaard, T. International Human Rights of Children. Springer: Singapore, 3-29.

8. Draghici, C. (2017). The Legitimacy of Family Rights in Strasbourg Case Law: 'Living Instrument' or Extinguished Sovereignty?. Oxford, Portland, Oregon: Hart Publishing.

9. Dropulić, J. (2006). Pravo na osobno ime. Hrvatska pravna revija 6(3), 121-138. 
Doc. dr. sc. Nataša Lucić: Zastupanje u vezi s bitnim osobnim pravima djeteta Zbornik radova Pravnog fakulteta u Splitu, god. 58, 3/2021, str. 815-840

10. Gavella, N. (2000). Osobna prava: I dio, Zagreb: Pravni fakultet Sveučilišta u Zagrebu.

11. Guerreiro, A. i Flotten, K. (2017). Article 12: The Translation into Practice of Children's Right to Participation in Health Care, u: ur. Liefaard, T. i Sloth-Nielsen, J. The United Nations Convention od the Rights of the Child: Taking Stock after 25 Years and Looking Ahead. Leiden, Boston: Brill, 681-707.

12. Hlača, N. (2014). Vjerski odgoj djece i pravo djeteta na slobodu vjeroispovjedi, u: ur. Žnidaršič Skubic, V., et al. Zbornik v čast Karla Zupančiča: Družinsko in dedno pravo, Ljubljana: Pravna fakulteta, str. 67-98

13. Hlača, N. i Popović, P. (2009). Pravo djeteta na slobodu savjesti i vjeroispovijesti. Bogoslovna smotra, 79(2), 275-303.

14. Hrabar, D. (2018). Odjek roditeljskih vjerskih i filozofskih uvjerenja na odgoj i obrazovanje djece u hrvatskoj legislativi. Zbornik Pravnog fakulteta u Zagrebu, 68(34), 319-336.

15. Jastram, K. i Newland, K. (2003). Family Unity and Refugee Protection, u: ur. Feller et al., Refugee Protection in International Law: UNHCR's Global Consultations on International Protection, Cambridge University Press.

16. Kilkelly, U. (2017). The Child and the European Convention on Human Rights. London, New York: Taylor \& Francis.

17. Kilkelly, U. i Liefaard, T. (2019). International Human Rights of Children. Springer: Singapore.

18. Korać Graovac, A. (2017). Od zajedničkog do samostalnog ostvarivanja roditeljske skrbi i natrag - kako zaštititi prava djece i roditelja. Godišnjak Akademije pravnih znanosti Hrvatske, 8(poseban broj), 51-73.

19. Langlaude, S. (2007). The Right of the Child to Religious Freedom in International Law. Leiden, Boston: Martinus Nijhoff Publishers.

20. Liefaard, T. i Sloth-Nielsen, J. (2017). The United Nations Convention od the Rights of the Child: Taking Stock after 25 Years and Looking Ahead. Leiden, Boston: Brill.

21. Lowe, N. (2016). The impact of the Council of Europe on European family law, u: Scherpe, J. M., European Family Law Vol. 1: The impact of the Institutions and Organisations on European Family Law, Cheltenham, Northampton: Edward Elgar Publishing, 95-123.

22. Lucić, N. i Marošević, K. (2020). Protection of child's right to a healthy environment in context of local development, u ur. Šimić, M. i Crnković, B., Region, Entrepreneurship, Development: 9th International Scientific Symposium, Osijek: Josip Juraj Strossmayer University of Osijek, Faculty of Economics in Osijek, 1088-1103.

23. Mirshekari, A. i Ketilate, A. F. (2020). A Child's Right to a Name: An Emphasis on the Iranian Legal System. Children's Legal Rights Journal, 40(2), 137-145.

24. Mol, C. (2019). Children's Representation in Family Law Proceedings. The International Journal of Children's Rights, 27(1), 66-98.

25. Parkinson,P., Cashmore, J. (2015). Reforming Relocation Law: An Evidence-Based Approach. Family Court Review, 53(1), 23-39. 
26. Pavelkova, B. (2013). Pravo rodieov na zmenu mena dietat'a a pravo dietata na zachovanie svojej identity. Pravny obzor, 96(1), 67-85.

27. Radina, A. (2018). Pravo djeteta na slobodu vjeroispovijedi. Doktorski rad, Zagreb: Pravni fakultet Sveučilišta u Zagrebu.

28. Radolović, A. (1998). Prava ličnosti u građanskom pravu Hrvatske. Vladavina prava 2(1), 73-93.

29. Rap, S. (2017). The Voice of the Child in Juvenile Justice Procedures, u: ur. Liefaard, T. i Sloth-Nielsen, J. The United Nations Convention od the Rights of the Child: Taking Stock after 25 Years and Looking Ahead. Leiden, Boston: Brill, 294-315.

30. Ravasi, E. (2017). Human Rights Protection by the ECtHR and the ECJ: A Comparative Analysis in Light of the Equivalency Doctrine, Leiden: Brill.

31. Rešetar, B. (2011). Pravna zaštita prava na susrete i druženje. Osijek: Sveučilište Josipa Jurja Strossmayera, Pravni fakultet Osijek.

32. Šago, D. (2017). Procesna prava djeteta, u: Rešetar et al., Suvremeno obiteljsko pravo i postupak, Osijek: Sveučilište Josipa Jurja Strossmayera, Pravni fakultet Osijek, 259290.

33. Winkler, S. (2014). The Right to a Name between the Personal Identity and the Belonging to a Family. Conference proceedings: Political sciences, law, finance, economics and tourism, 885-892.

34. Winkler, S. (2013). Pravo na osobno ime u praksi europskih sudova, u: Bodiroga et al., Europsko obiteljsko pravo, Zagreb: Narodne novine d.d., 125-143.

\section{Propisi}

1. Deklaracija o ukidanju svih oblika nesnošljivosti i diskriminacije na temelju vjere i uvjerenja (Proglašeno Rezolucijom Generalne skupštine 36/55 od 25. studenoga 1981.)

2. Konvencija o pravima djeteta (Narodne novine - Međunarodni ugovori br. 12/93, 20/97, 4/98, 13/98, 5/02, 7/02, 2/03, 2/17, 4/17)

3. Konvencija o pravima osoba s invaliditetom (Narodne novine - Međunarodni ugovori br. 6/07, 3/08, 5/08)

4. Konvencija za zaštitu ljudskih prava i temeljnih sloboda (Narodne novine Međunarodni ugovori br. 18/97, 6/99, 8/99, 14/02, 13/03, 9/05, 1/06, 2/10, 13/17)

5. Međunarodni pakt o građanskim i političkim pravima (Narodne novine - Međunarodni ugovori br. 12/93, 7/95, 11/95)

6. Obiteljski zakon (Narodne novine br. 103/15, 98/19)

7. Povelja Europske unije o temeljnim pravima (Službeni list Europske unije, 2007/C 303/01)

8. Preporuka CM / Rec (2015) 4 o sprečavanju i rješavanju sporova oko preseljenja djece

9. Zakon o odgoju i obrazovanju u osnovnoj i srednjoj školi (Narodne novine br. 87/08, 86/09, 92/10, 105/10, 90/11, 5/12, 16/12, 86/12, 126/12, 94/13, 152/14, 07/17, 68/18, $98 / 19,64 / 20,133 / 20)$ 
10. Zakon o osobnom imenu (Narodne novine br. 118/12, 70/17, 98/19)

11. Zakon o prebivalištu (Narodne novine br. 144/12, 158/13, 115/14)

12. Ustav Republike Hrvatske (Narodne novine br. 56/90, 135/97, 113/00, 28/01, 76/10, $5 / 14)$

\section{Praksa Europskog suda za ljudska prava}

1. A. i B. protiv Hrvatske, Zahtjev br. 7144/15, Odluka od 20. lipnja 2019.

2. Bayatyan protiv Armenije (zahtjev br. 23459/03, presuda od 7. srpnja 2011.

3. Bijleveld protiv Nizozemske, Zahtjev br. 42973/98, Odluka od 27. travnja 2000.

4. Burghartz protiv Švicarske, Zahtjev br. 16213/90, Odluka od 22. veljače 1994.

5. Cuzan i Fazzo protiv Italije, Zahtjev br. 77/07, Odluka od 7. siječnja 2014.

6. Grzelak protiv Poljske, Zahtjev br. 7710/02, Odluka od 15. lipnja 2010.

7. Guillot protiv Francuske, Zahtjev br. 22500/93, Odluka od 24. listopada 1996.

8. Hoffman protiv Austrije, Zahtjev br. 12875/87, Odluka od 23. lipnja 1993.

9. Hagmann-Hüsler protiv Švicarske, Zahtjev br. 8042/77, Odluka od 15. prosinca 1997.

10. Hokkanen protiv Finske, Zahtjev br. 19823/92, Odluka od 23. rujna 1994.

11. Ismailova protiv Rusije, Zahtjev br. 37614/02, Odluka od 29. prosinca 2007.

12. Johansson protiv Finske, Zahtjev br. 10163/02, Odluka od 6. rujna 2007.

13. Kjeldsen, Busk Madsen i Pedersen protiv Danske, Zahtjev br. 5095/71; 5920/72; 5926/72, Odluka od 7. prosinca 1976.

14. Kosmopoulou protiv Grčke, Zahtjev br. 60457/00, Odluka od 5. veljače 2004.

15. Losonci Rose i Rose protiv Švicarske, Zahtjev br. 664/06, Odluka od 9. studenog 2010.

16. Paradiso i Campanelli protiv Italije, Zahtjev br. 25358/12, Odluka od 24. siječnja 2017.

17. Palau-Martinez protiv Francuske, Zahtjev br. 64927/01, Odluka od 16. prosinca 2003.

18. Sahin protiv Njemačke, Zahtjev br. 30943/96, Odluka od 8. srpnja 2003.

19. Ünal Tekeli protiv Turske, Zahtjev br. 29865/96, Odluka od 6. studenog 2004.

\section{Mrežni izvori}

1. Ministarstvo pravosuđa i sigurnosti Nizozemske: https://www.justis.nl/producten/ naamswijziging/achternaam-minderjarige-wijzigen/index.aspx

2. Riel, J. (2010). Parental rights in a religious context: An analysis of protection provided by the European Court of Human Rights Parental rights in a religious context: http:// arno.uvt.nl/show.cgi?fid=122325

3. Vlada Ujedinjenog Kraljevstva: https://www.gov.uk/change-name-deed-poll/changea-childs-name 


\section{REPRESENTATION IN RELATION TO THE ESSENTIAL PERSONAL RIGHTS OF THE CHILD}

The theme of this paper is representation in relation to the essential personal rights of the child which, according to national family law legislation, essentially includes representation in connection with the change of the child's personal name, change of residence of the child and choice or change of the child's religion. Representation of the child is the content of parental responsibilty and in exercising of parental responsibilty the parents are completely equal. In this sense, in situations where there is no agreement between the parents on the essential personal rights of the child, it is demanding to generate solutions that will protect the best interests of the child, and at the same time will not jeopardize the equal position of parents as his/her legal representatives. The paper also discusses representation in relation to the essential personal rights of the child when the child does not have adequate parental care and of the role of guardian in such circumstances. The aim of this paper is to assess the current legal situation in the field of representation in relation to the essential personal rights of the child, based at the analysis of relevant regulations at national, European and international level, and to give de lege ferenda proposals that will contribute to harmonization of national regulations in this legal area.

Key words: child, representation, essential personal rights, parental care 